\title{
The Correlation of ${ }^{113} \mathrm{Cd}$ NMR and ${ }^{111 \mathrm{~m} C d}$ PAC Spectroscopies Provides a Powerful Approach for the Characterization of the Structure of Cd"-Substituted Zn" Proteins**
}

\author{
Olga Iranzo ${ }^{a}$, Tamas Jakusch ${ }^{a}$, Kyung-Hoon Lee $^{a}$, Lars Hemmingsen ${ }^{b}$, and Vincent L. \\ Pecoraro*,a \\ aDepartment of Chemistry, University of Michigan, Ann Arbor, Michigan 48109-1055 (USA) \\ bBioinorganic Chemistry Group, IGM, Faculty of Life Sciences, University of Copenhagen, \\ Thorvaldsensvej 40, 1871 Frederiksberg C (Denmark)
}

\section{Abstract}

$\mathrm{Cd}^{\mathrm{II}}$ has been used as a probe of zinc metalloenzymes and proteins because of the spectroscopic silence of $\mathrm{Zn}$ II. One of the most commonly used spectroscopic techniques is ${ }^{113} \mathrm{Cd}$ NMR; however, in recent years ${ }^{111 \mathrm{~m}} \mathrm{Cd}$ Perturbed Angular Correlation spectroscopy $\left({ }^{111 \mathrm{~m}} \mathrm{Cd}\right.$ PAC) has also been shown to provide useful structural, speciation and dynamics information on $\mathrm{Cd}^{\mathrm{II}}$ complexes and biomolecules. In this article, we show how the joint use of ${ }^{113} \mathrm{Cd} \mathrm{NMR}$ and ${ }^{111 \mathrm{~m}} \mathrm{Cd}$ PAC spectroscopies can provide detailed information about the $\mathrm{Cd}^{\mathrm{II}}$ environment in thiolate-rich proteins. Specifically we show that the ${ }^{113} \mathrm{Cd}$ NMR chemical shifts observed for $\mathrm{Cd}^{\mathrm{II}}$ in the designed TRI series (TRI = Ac-G-(LKALEEK) $)_{4} \mathrm{G}_{-} \mathrm{NH}_{2}$ ) of peptides vary depending on the proportion of trigonal planar $\mathrm{CdS}_{3}$ and pseudotetrahedral $\mathrm{CdS}_{3} \mathrm{O}$ species present in the equilibrium mixture. PAC spectra are able to quantify these mixtures. When one compares the chemical shift range for these peptides (from $\delta=570$ to $700 \mathrm{ppm}$ ), it is observed that $\mathrm{CdS}_{3}$ species have $\delta 675-700 \mathrm{ppm}, \mathrm{CdS}_{3} \mathrm{O}$ complexes fall in the range $\delta 570-600 \mathrm{ppm}$ and mixtures of these forms fall linearly between these extremes. If one then determines the $\mathrm{p} K_{\mathrm{a} 2}$ values for $\mathrm{Cd}^{\mathrm{II}}$ complexation $\left[\mathrm{p} K_{\mathrm{a} 2} \text { is for the reaction } \mathrm{Cd}\left[(\text { peptide }-\mathrm{H})_{2}(\text { peptide })\right]^{+} \rightarrow \mathrm{Cd} \text {-(peptide) }\right)_{3}{ }^{-}+2 \mathrm{H}^{+}$and compares these to the observed chemical shift for the $\mathrm{Cd}$ (peptide) ${ }_{3}{ }^{-}$complexes, one finds that there is also a direct linear correlation. Thus, by determining the chemical shift value of these species, one can directly assess the metal-binding affinity of the construct. This illustrates how proteins may be able to fine tune metal-binding affinity by destabilizing one metallospecies with respect to another. More important, these studies demonstrate that one may have a broad ${ }^{113} \mathrm{Cd}$ NMR chemical shift range for a chemical species (e.g., $\mathrm{CdS}_{3} \mathrm{O}$ ) which is not necessarily a reflection of the structural diversity within such a four-coordinate species, but rather a consequence of a fast exchange equilibrium between two related species (e.g., $\mathrm{CdS}_{3} \mathrm{O}$ and $\mathrm{CdS}_{3}$ ). This could lead to reinterpretation of the assignments of cadmium-protein complexes and may impact the application of $\mathrm{Cd}^{\mathrm{II}}$ as a probe of $\mathrm{Zn}^{\mathrm{II}}$ sites in biology.

\section{Keywords}

cadmium; metallopeptides; NMR spectroscopy; zinc proteins

\footnotetext{
** PAC Spectroscopy = perturbed angular correlation spectroscopy Supporting information for this article is available on the WWW under http://dx.doi.org/10.1002/chem.200802105: Models and equations for extended model calculations in order to fit the UV/Vis $\mathrm{pH}$ titration curves; $\mathrm{p} K$ for several equilibria determined for several peptides: 1) TRIL16Pen, 3) GRANDL16Pen, 4) TRIL16CL23A, 6) BABYL9C, 10) GRANDL9C, 12) TRIL9AL16C, 13) TRIL12AL16Pen, 14) TRIL12AL16C.

(C) 2009 Wiley-VCH Verlag GmbH \& Co. KGaA, Weinheim

Fax: (+1) 734-936-7628, vlpec@umich.edu.
} 


\section{Introduction}

Zinc proteins are among the most abundant metalloproteins, with the metal center either having a catalytic role or a structural role. These ubiquitous metalloproteins are involved in extraordinarily diverse processes which extend from hydrolytic reactions in metabolism to gene regulation (transcription factors), DNA repair and post-transcriptional modification of proteins. ${ }^{[1-10]}$ In addition, the advent of proteomics is increasing our recognition of the number of proteins that require $\mathrm{Zn}^{\mathrm{II}}$ either as a catalytic and/or structural element. ${ }^{[11]}$ This utilization is not surprising since zinc is an abundant trace metal, found second only to iron in eukaryotic organisms. Therefore, to clarify fully metallobiochemistry, one needs a deep understanding of the structural aspects defining different zinc-binding sites and how the protein framework proficiently modulates the properties of this metal ion to perform, in each case, the required function.

Unlike other common metals in biology, zinc is promiscuous with respect to the types and number of ligands bound to it in proteins. One can observe structures that are low coordination number (e.g., 4), sulfur-rich centers to moderate coordination number (5 or 6) environments that are oxygen and nitrogen rich. Unfortunately, due to the poor spectroscopic properties of $\mathrm{Zn}^{\mathrm{II}}$, a diamagnetic closed shell $\mathrm{d}^{10}$ ion, it is difficult to obtain information regarding the structure of these binding sites and, in the case of enzymes, of their mechanisms of action. To overcome this drawback, scientists have widely replaced $\mathrm{Zn}^{\mathrm{II}}$ with other metal ions that have useful spectroscopic properties. ${ }^{[12,13]}$

$\mathrm{Cd}^{\mathrm{II}}$ has often been employed as a probe to understand $\mathrm{Zn}^{\mathrm{II}}$-binding sites. This is because $\mathrm{Cd}^{\mathrm{II}}$-coordination preferences resemble the broad coordination number and ligand affinities of $\mathrm{Zn}{ }^{\mathrm{II}}$, but permits the use of ${ }^{113} \mathrm{Cd}$ NMR spectroscopy—an extremely useful and accessible technique that is very sensitive to the type and number of ligands bound to $\mathrm{Cd}^{\mathrm{II}} \cdot{ }^{[12,14,15]}$ Less used, but gaining recognition, is ${ }^{111 \mathrm{~m}} \mathrm{Cd}$ Perturbed Angular Correlation (PAC) spectroscopy. ${ }^{[16]}$ Until recently, ${ }^{113} \mathrm{Cd}$ NMR and ${ }^{111 \mathrm{~m}} \mathrm{Cd}$ PAC spectroscopies were rarely used in combination to study natural metal-binding sites, and in fact, few examples exist in the literature. ${ }^{[17-19]}$ Both methods are highly sensitive to the $\mathrm{Cd}^{\mathrm{II}}$ first coordination sphere and provide complementary dynamics information because of the different timescale of the methods. Thus, the combined use of these two techniques could be a valuable strategy to probe $\mathrm{Cd}^{\mathrm{II}}$-substituted $\mathrm{Zn}^{\mathrm{II}}$-binding sites in biomolecules; however, the expectation for establishing a proper structural interpretation can only be realized once a systematic correlation of the ${ }^{113} \mathrm{Cd}$ NMR and ${ }^{111 \mathrm{~m}} \mathrm{Cd}$ PAC signatures of $\mathrm{Cd}^{\mathrm{II}}$ in well defined environments exists.

Our group has used a de novo design approach to define the chemistry of $\mathrm{Cd}^{\mathrm{II}}$ in a thiolaterich environment as might be found in $\mathrm{CadC}^{[20]}$ or cadmium substituted $\mathrm{Zn}^{\mathrm{II}}$ proteins, such as aminolevulinic acid dehydratase (ALAD) ${ }^{[21]}$ or the hepatitis $\mathrm{C}$ virus $\mathrm{NS}_{3}$ protease domain. ${ }^{[22]}$ The TRI peptide family $\left(\text { TRI }=\text { Ac-G }(\text { LKALEEK })_{4} \mathrm{G}_{-} \mathrm{NH}_{2} \text {, Table } 1\right)^{[23,24]}$ utilizes a heptad repeat unit that contains hydrophobic residues, usually Leu, in the 1st ("a") and 4th ("d") positions, generating an amphiphatic a-helix that in aqueous solution associates above $\mathrm{pH} 6.0$ to form three-stranded coiled coils. We have been studying the binding of $\mathrm{Cd}^{\mathrm{II}}$ to different TRI peptides where a single Leu, either in position "a" or "d", was replaced by a Cys to generate a thiol-rich binding site inside the hydrophobic core of these coiled coils. ${ }^{[25-29]}$ These peptides are the perfect scaffolds as they are much simpler than the natural systems but retain enough structural complexity to study how the protein framework can modulate the geometries and physical properties of metal ions bound to thiol-rich centers. By combining ${ }^{113} \mathrm{Cd}$ NMR and ${ }^{111 \mathrm{~m} C d ~ P A C}$ spectroscopies, we have shown how the peptide TRIL16C binds $\mathrm{Cd}^{\mathrm{II}}$ as a mixture of pseudotetrahedral $\left(\mathrm{CdS}_{3} \mathrm{O}\right)$ and 
trigonal planar $\left(\mathrm{CdS}_{3}\right)$ structures. ${ }^{[25]}$ Subtle changes in the amino acid sequence of the parent peptide were sufficient to generate two peptides, TRIL12AL16C and TRIL16Pen, that bind $\mathrm{Cd}^{\mathrm{II}}$ exclusively in the $\mathrm{CdS}_{3} \mathrm{O}$ and $\mathrm{CdS}_{3}$ geometries, respectively. ${ }^{[30]}$ Furthermore, these techniques have driven our design strategy for the heterochromic peptide,

GRANDL16PenL26AL30C, a single peptide containing two binding sites within the same three-stranded coiled coil which is capable of binding two $\mathrm{Cd}^{\mathrm{II}}$ with different physical properties and showing site-selective $\mathrm{Cd}^{\mathrm{II}}$ recognition. ${ }^{[31]}$ The combination of the ${ }^{113} \mathrm{Cd}$ NMR and ${ }^{111 \mathrm{~m}} \mathrm{Cd}$ PAC spectroscopic data has been crucial to the characterization of these peptides to high chemical resolution.

The ${ }^{113} \mathrm{Cd}$ NMR and ${ }^{111 \mathrm{~m}} \mathrm{Cd}$ PAC spectroscopic data also provide useful information on the chemical exchange because of the different time scales probed by these techniques [NMR (0.01-10 ms); ${ }^{111 \mathrm{~m}} \mathrm{Cd}$ PAC $(0.1-100 \mathrm{~ns}) .{ }^{[25,28]}$ For a peptide, such as TRIL16C, a single resonance $(625 \mathrm{ppm})$ is observed suggesting that a single $\mathrm{Cd}$ structure is present; however, PAC studies revealed the existence of the $\mathrm{CdS}_{3} \mathrm{O}$ and $\mathrm{CdS}_{3}$ species. Based on these observations, we have been able to place a limitation on the exchange rate for the oxygen of the $\mathrm{CdS}_{3} \mathrm{O}$ species as being between $0.01-10 \mathrm{~ms}$. More important, these data reveal an important caveat when using ${ }^{113} \mathrm{Cd} \mathrm{NMR}$ as the sole method of defining the metalcoordination sphere. In cases, where ligand exchange occurs, the chemical shift range for the ${ }^{113} \mathrm{Cd}$ NMR may not alone be representative of the true speciation of a system.

Here we present a systematic study of $\mathrm{CdS}_{3} \mathrm{O}$ and $\mathrm{CdS}_{3}$ centers in selected peptides that are analyzed by ${ }^{113} \mathrm{Cd}$ NMR, ${ }^{111 \mathrm{~m}} \mathrm{Cd} \mathrm{PAC}$ and UV/Vis spectroscopies. Important linear correlations are observed between ${ }^{113} \mathrm{Cd}$ NMR and ${ }^{111 \mathrm{~m}} \mathrm{Cd}$ PAC spectroscopies and the acid/base properties of the metal-binding site that allows one to identify the proportion of three- and four-coordinate sites in any peptide. These types of correlations are very hard to obtain in native systems since they require a system capable of accommodating different metal coordination geometries while keeping basically the same overall structure. Indeed, to the best of our knowledge, there are no reports in the literature where this type of data, ${ }^{111 \mathrm{~m}} \mathrm{Cd} \mathrm{PAC}-{ }^{113} \mathrm{Cd}$ NMR-Cd ${ }^{\mathrm{II}}$ binding acidity, has been correlated either for native systems or small molecules. Since numerous zinc proteins bind $\mathrm{Zn}^{\mathrm{II}}$ with thiolate ligands, ${ }^{[7,9,21,22,32-37]}$ and $\mathrm{Cd}^{\mathrm{II}}$ substitution is quite often used to study these binding sites, the results reported here can shed light into understanding better $\mathrm{Cd}^{\mathrm{II}}$-substituted thiolaterich zinc proteins.

\section{Results}

\section{$111 \mathrm{~m} C d$ Perturbed Angular Correlation (PAC) spectroscopy}

${ }^{111 \mathrm{~m}} \mathrm{Cd}$ PAC spectroscopy was used to determine the $\mathrm{Cd}^{\mathrm{II}}$ coordination geometry of the different TRI peptides complexes. The ${ }^{111 \mathrm{~m}} \mathrm{Cd}$ PAC spectra for different peptides of the TRI family are shown in Figure 1. The PAC data were analyzed as described in the Experimental Section. Each nuclear quadrupole interaction (NQI) was modelled using a separate set of parameters that includes $\omega_{0}, \eta, \Delta \omega_{0 /} \omega_{0}, 1 / \tau_{\mathrm{c}}$ and $A$. The parameters fitted to the PAC data for each peptide complex are reported in Table 2 . All the NQIs have relatively low values of $\eta$, the asymmetry parameter, indicating that there is symmetry around the $Z$ axis which is the principal axis of the electric field gradient tensor with the largest eigenvalue. All the values of $\omega_{0}$, the parameter giving information regarding the first coordination sphere ligands, fall into two frequency regions, one around $0.450 \mathrm{rad} \mathrm{ns}^{-1}$ and the other around $0.340 \mathrm{rad} \mathrm{ns}^{-1}$. This indicates that two coordination geometries, trigonal planar $\left(\omega_{0}=0.450 \mathrm{rad} \mathrm{ns}^{-1}\right)$ and distorted tetrahedral $\left(\omega_{0}=0.340 \mathrm{rad} \mathrm{ns}^{-1}\right)$, may adequately describe the metal site structures in all these peptides. The PAC spectroscopic data for the peptides TRIL9AL16C and TRIL12AL16Pen give in both cases a well defined NQI with $\omega_{0}$ and $\eta$ values of $0.3332 \mathrm{rad} \mathrm{ns}^{-1}$ and 0.19 , and $0.339 \mathrm{rad} \mathrm{ns}^{-1}$ and 0.36 , respectively. 
These values are similar to the value observed for the peptide TRIL12AL16C with a $\omega_{0}=$ $0.3405 \mathrm{rad} \mathrm{ns}^{-1}$ and $\eta=0.141,{ }^{[30]}$ and may correspond to a distorted tetrahedral $\mathrm{CdS}_{3} \mathrm{O}$ species. The NQI for the peptide containing the Pen substitution, TRIL12AL16Pen, has the highest value of $\eta(0.36)$ in comparison with the other two peptides which is indicative of a larger perturbation of the geometry from axial symmetry. The peptides TRIL16-CL23A and TRIL12VL16Pen give PAC spectra showing two NQIs which are similar to those found for the peptide TRIL16C. ${ }^{[25]}$ These results indicate that $\mathrm{Cd}^{\mathrm{II}}$ binds to these peptides as a mixture of distorted tetrahedral $\mathrm{CdS}_{3} \mathrm{O}$ species (lower frequency species) and distorted trigonal planar $\mathrm{CdS}_{3}$ species (higher frequency species). For the peptide TRIL16-CL23A, there is a similar occupation of the two geometries since the amplitude of both frequencies is similar. However, for TRIL12VL16Pen, there is a dominating species and this belongs to the high-frequency group. The low-frequency component is difficult to fit due to the low amplitude of this signal. Thus, in order to limit the number of free parameters fitted to this NQI, the $\omega_{0}, \eta, \Delta \omega_{0} / \omega_{0}$ and $1 / \tau_{\mathrm{c}}$ values were fixed to the values of low frequency component found for the TRIL16C peptide. Different parameters fitted to the low frequency signal may give equally good $\chi_{\mathbf{r}}^{2}$ values. A relative high $1 / \tau_{c}$ value is observed for the signals in all the peptides containing the Pen substitution species (Table 2, see last three rows). This is indicative of local dynamics at the metal ion binding site that occur on the nanosecond timescale. For TRIL16CL23A an experiment was carried out without TRIS buffer and no significant change of the spectrum was observed.

\section{UV/Vis spectroscopy}

The $\mathrm{pH}$ dependence of $\mathrm{Cd}^{\mathrm{II}}$ binding to the thiol groups of different peptides was followed by monitoring the formation of the characteristic ligand to metal charge transfer (LMCT) band at $235 \mathrm{~nm} \cdot{ }^{[27,29]}$ For those experiments where $\mathrm{Cd}^{\mathrm{II}}$ was binding to the peptides TRIL16Pen, GRANDL16Pen and TRIL12VL16Pen, longer equilibration times after addition of $\mathrm{KOH}$ were in general required. Figure 2 shows the $\mathrm{pH}$ profiles for several of the peptides of the TRI family. The experimental data was fit using the model published previously that corresponds to the simultaneous release of the two protons (see Experimental Section). ${ }^{[27]}$ This model implies the formation of the species $\mathrm{Cd}\left[(\text { peptide- } \mathrm{H})_{2} \text { (peptide) }\right]^{+}$at low $\mathrm{pH}$. The apparent acidity constant $K_{\mathrm{a} 2}$ has thus units of molar squared $\left(\mathrm{M}^{2}\right)$ and the apparent $\mathrm{p} K_{\mathrm{a} 2}$ values determined for each peptide are reported in Table 3 . The experimental data was also fit using an extended model that did not imply the full formation of the species $\mathrm{Cd}$ [(peptide$\mathrm{H})_{2}$ (peptide) $]^{+}$and included different equilibria (see Supporting Information). Although the values obtained for $\mathrm{p} K_{\mathrm{a} 2}$ are slightly different, the information they provide is identical and the same trend is observed (see Discussion and Figure S1).

\section{${ }^{113}$ Cd NMR spectroscopy}

The ${ }^{113} \mathrm{Cd}$ NMR spectra of the different $\mathrm{Cd}^{\mathrm{II}}$ peptide complexes were recorded at $\mathrm{pH}$ values where, based on the $\mathrm{pH}$ titrations, the metal ion was fully bound ( $\mathrm{pH} 8.5-9.0)$. In all cases, a single resonance is observed and the ${ }^{113} \mathrm{Cd}$ chemical shifts obtained (Table 3 ) are consistent with thiol coordination to $\mathrm{Cd}^{\mathrm{II}}\left[{ }^{[14,38]}\right.$

\section{Discussion}

Proteins harness the chemical properties of $\mathrm{Zn}^{\mathrm{II}}$ in order to perform a large variety of important cellular functions. The most common zinc binding sites are distorted tetrahedral $\mathrm{Zn}^{\mathrm{II}}$ centers where the metal ion is typically bound to nitrogen, oxygen and sulfur donor ligands. Usually the amino acids defining these binding pockets are His (N), Cys (S), Glu $(\mathrm{O})$ and $\operatorname{Asp}(\mathrm{O})$, with the first two amino acids being the most prevalent donors. ${ }^{[1,39]}$ Thiolate-rich binding centers are found in proteins implicated in very different biological activities, including gene regulation, methyl transfer reactions and protein 
modification. ${ }^{[7,9,10,32-34,40,41]}$ Surprisingly, despite possessing a common tetrahedral geometry and similar binding pockets, these thiolaterich $\mathrm{Zn}^{\mathrm{II}}$ centers are accurately tuned to carry out their distinct biological function. Therefore, it has become clear that besides the chemical nature of the coordinating amino acids, there are additional features of the metal environment which control the properties of $\mathrm{Zn}^{\mathrm{II}}$. Unfortunately, a clear knowledge of the structural, thermodynamic and kinetic factors that differentially modulate the chemical and physical properties of $\mathrm{Zn}^{\mathrm{II}}$ bound to these sites is sparse. This lack of information stems, to some extent, from the fact that $\mathrm{Zn}^{\mathrm{II}}$ is not amenable to most forms of spectroscopies, which complicates the direct study of the zinc-binding properties of these proteins. The use of $\mathrm{Cd}^{\mathrm{II}}$ as a probe to study naturally containing $\mathrm{Zn}^{\mathrm{II}}$ proteins has been one of the most employed alternatives, since this metal replacement opens the door to the use of ${ }^{113} \mathrm{Cd} \mathrm{NMR}$ and ${ }^{111 \mathrm{~m}} \mathrm{Cd}$ PAC spectroscopies. ${ }^{[12,14,16]}$

Our group is now in the position to start analyzing in great detail specific thiol-rich binding sites using de novo designed peptides. These peptides sequester $\mathrm{Cd}^{\mathrm{II}}$ by enforcing a pseudotetrahedral $\mathrm{S}_{3} \mathrm{O}$ first coordination sphere. The fourth ligand, thought to be an exogenous water molecule, can be present or not, generating in the last case a trigonal planar $\mathrm{S}_{3}$ coordination site. The significance of studying these systems lays in the fact that in zinc enzymes, the $\mathrm{Zn}^{\mathrm{II}}$ center normally possesses three permanent coordinating positions occupied by amino acid ligands and the fourth site is filled either with an exogenous water/ hydroxide molecule, which is very important for catalysis, a fourth amino acid or serves as the location of substrate binding. ${ }^{[1-3,22,34,35,42]}$

We have successfully designed two peptides, TRIL12AL16C and TRIL16Pen, capable of binding $\mathrm{Cd}^{\mathrm{II}}$ exclusively in pseudotetrahedral $\left(\mathrm{S}_{3} \mathrm{O}\right)$ and trigonal planar $\left(\mathrm{S}_{3}\right)$ geometries, respectively. ${ }^{[30]}$ These $\mathrm{Cd}^{\mathrm{II}}$ complexes, $\left[\mathrm{Cd}(\text { TRIL12AL16C) })_{3}\right]^{-}$and $\left[\mathrm{Cd}(\text { TRIL16Pen })_{3}\right]^{-}$, possess very different ${ }^{113} \mathrm{Cd}$ NMR and ${ }^{111 \mathrm{~m}} \mathrm{Cd}$ PAC spectral signatures

([Cd(TRIL12AL16C) $\left.)_{3}\right]^{-}: 574 \mathrm{ppm}$ and $\omega_{0}=0.3405 \mathrm{rad} \mathrm{ns}^{-1} ;$ [Cd(TRIL16Pen) $\left.)_{3}\right]^{-}: 684$ ppm and $\omega_{0}=0.454 \mathrm{rad} \mathrm{ns}^{-1}$; Tables 2 and 3 ). We have proposed that these spectroscopic properties are the result of the different $\mathrm{Cd}^{\mathrm{II}}$-coordination numbers and geometries. As support for this model, the parent TRIL16C peptide, when interrogated with ${ }^{111 \mathrm{~m} C d \text { PAC }}$ spectroscopy, appears to bind $\mathrm{Cd}^{\mathrm{II}}$ as a mixture of both species (with two different signature signals $\left(\omega_{0}=0.3405 \mathrm{rad} \mathrm{ns}^{-1}\right.$ and $\left.\omega_{0}=0.454 \mathrm{rad} \mathrm{ns}^{-1}\right)$, while a single coalesced ${ }^{113} \mathrm{Cd}$ NMR resonance (625 ppm) is observed. ${ }^{[25]}$

Two important observations can be inferred from these data. First, that both species, a pseudotetrahedral $\mathrm{CdS}_{3} \mathrm{O}$ and trigonal planar $\mathrm{CdS}_{3}$, interconvert rapidly on the NMR timescale $(0.01-10 \mathrm{~ms})$ but slowly on the PAC timescale $(0.1-100 \mathrm{~ns}){ }^{[25,28]}$ The best model to describe this system is a fast water exchange that interconverts the three- and fourcoordinate sites quickly. Considering the timescale of both techniques, this water exchange process occurs in the range of ms to ns, a value consistent with the water exchange rates reported for solvated $\mathrm{Cd}^{\mathrm{II}} .{ }^{[43]}$ Second, this model predicts that there should be a linear correlation between the chemical shift in the ${ }^{113} \mathrm{Cd}$ NMR spectrum and the ratio of $\mathrm{CdS}_{3} \mathrm{O} /$ $\mathrm{CdS}_{3}$ extracted from the ${ }^{111 \mathrm{~m}} \mathrm{Cd} \mathrm{PAC}$ spectrum. If the existence of this correlation is true, then the ${ }^{113} \mathrm{Cd}$ NMR chemical shift (which experimentally is more generally available than PAC) could be used as an extremely sensitive indicator of the percentage of four-coordinate $\mathrm{CdS}_{3} \mathrm{O}$ and three-coordinate $\mathrm{CdS}_{3}$ species present in solution.

To assess this last point, we studied a wide range of peptides in the TRIL16C family (TRIL9AL16C, TRIL16CL23A and TRIL12VL16Pen) using ${ }^{111 \mathrm{~m}} \mathrm{Cd}$ PAC spectroscopy. These peptides were chosen because their ${ }^{113} \mathrm{Cd}$ NMR chemical shifts (Table 3) predicted either pure $\mathrm{CdS}_{3} \mathrm{O}$ or $\mathrm{CdS}_{3}$ species, or a mixture of both species co-existing. In all cases, the NQIs obtained (Table 2) have values of $\omega_{0}$ that fall into the two frequency regions obtained 
for the pure species [Cd(TRIL12AL16C) $\left.)_{3}\right]^{-}\left(\omega_{0}=0.3405 \mathrm{rad} \mathrm{ns}^{-1}\right)$ and $\left.\operatorname{Cd}(\text { TRIL16Pen })_{3}\right]^{-}\left(\omega_{0}=0.454 \mathrm{rad} \mathrm{ns}^{-1}\right)$, indicating that these peptides can in fact be described using the same type of geometries. While the complex [Cd(TRIL9AL16C) $\left.{ }_{3}\right]^{-}$can be described as a $100 \% \mathrm{CdS}_{3} \mathrm{O}$ species, the other two peptides, TRIL16CL23A and TRIL12VL16Pen, bind $\mathrm{Cd}^{\mathrm{II}}$ as a mixture of $\mathrm{CdS}_{3} \mathrm{O}$ and $\mathrm{CdS}_{3}$. It is worthwhile to note here that the substitution of Leu to Ala above the plane of the Cys seems to selectively stabilize the $\mathrm{CdS}_{3} \mathrm{O}$ structure since in both cases, TRIL12AL16C and TRIL9AL16C, $\mathrm{Cd}^{\mathrm{II}}$ binds exclusively as a four-coordinate $\mathrm{CdS}_{3} \mathrm{O}$ species. Figure 3 shows a plot of the percentage of the four-coordinate species $\mathrm{CdS}_{3} \mathrm{O}$, calculated based on the ${ }^{111 \mathrm{~m}} \mathrm{Cd} \mathrm{PAC}$ spectroscopic data (Table 3), against the corresponding ${ }^{113} \mathrm{Cd}$ NMR chemical shift for the different TRI peptides. The graphic obtained indicates that indeed there is a linear correlation between both spectroscopic signatures that follows the percentage speciation between the four- and three-coordinate species. This linear correlation predicts a theoretical ${ }^{113} \mathrm{Cd}$ NMR chemical shift of $579 \mathrm{ppm}$ for the four-coordinate $\mathrm{CdS}_{3} \mathrm{O}$ species and of $702 \mathrm{ppm}$ for the threecoordinate $\mathrm{CdS}_{3}$ complex. This last value is very close to the ${ }^{113} \mathrm{Cd}$ NMR chemical shift predicted previously $(698 \mathrm{ppm}) .{ }^{[30]}$ Our more recent result supports this prediction since the peptide TRIL12 $_{\mathbf{d}} \mathbf{L} \mathbf{L C C}$ binds $\mathrm{Cd}^{\mathrm{II}}$ with a $100 \%$ trigonal planar geometry, as determined by ${ }^{111 \mathrm{~m}} \mathrm{Cd}$ PAC spectroscopy, and has a ${ }^{113} \mathrm{Cd}$ NMR chemical shift of $697 \mathrm{ppm} .{ }^{[44]}$ Using ${ }^{113} \mathrm{Cd}$ NMR spectroscopy and this linear correlation one can calculate the $\mathrm{Cd}^{\mathrm{II}}$ speciation present in solution for each of our peptidic systems with very high precision. If one considers that usually ${ }^{111 \mathrm{~m}} \mathrm{Cd} \mathrm{PAC}$ spectroscopy can determine the per cent of the different species in solution to within $10 \%$ accuracy, a ${ }^{113} \mathrm{Cd}$ NMR chemical shift in the range of 570-600 ppm, and of 675-700 ppm, can be expected for $\mathrm{Cd}^{\mathrm{II}}$ bound as a $\mathrm{CdS}_{3} \mathrm{O}$ and $\mathrm{CdS}_{3}$, respectively. This ${ }^{113} \mathrm{Cd}$ NMR spectral window is consistent with that observed for similar thiol-rich environments. ${ }^{[14,15]}$

We know that the TRIL12AL16C and TRIL16Pen peptides possess a very different $\mathrm{pH}$ profile for $\mathrm{Cd}^{\mathrm{II}}$ binding. ${ }^{[31]}$ As Figure 2 shows, the complex [Cd(TRIL12AL16C) $\left.)_{3}\right]^{-}$is fully formed at $\mathrm{pH} 7.5$ with a $\mathrm{p} K_{\mathrm{a} 2}$ value of 12.2 , while a higher $\mathrm{pH}$ is required to obtain the complex $\left[\mathrm{Cd}(\text { TRIL16Pen })_{3}\right]^{-}$, which has a $\mathrm{p} K_{\mathrm{a} 2}$ value of 15.8 . Therefore, $\mathrm{Cd}^{\mathrm{II}}$ has a lower $\mathrm{p} K_{\mathrm{a} 2}$ of binding to the four-coordinate site (TRIL12AL16C) compared to the three-

coordinate site (TRIL16Pen). This behavior was also observed in the heterochromic peptide GRANDL16PenL26AL30C ${ }^{[31]}$ Shown in the same Figure 2 there is the $\mathrm{pH}$ profile for $\mathrm{Cd}^{\mathrm{II}}$ binding to the parent peptide TRIL16C that binds this metal ion as a mixture of four- and three-coordinate species. This $\mathrm{pH}$ profile is intermediate between those obtained for the formation of the complexes $\left[\mathrm{Cd}(\text { TRIL12AL16C) })_{3}\right]^{-}$and $\left[\mathrm{Cd}(\text { TRIL16Pen })_{3}\right]^{-}$, suggesting that the $\mathrm{p} K_{\mathrm{a} 2}$ value for the formation of the different $\mathrm{Cd}^{\mathrm{II}}$ complexes could also be reflecting the speciation present in solution. If this is the case, and one considers that the ${ }^{113} \mathrm{Cd}$ NMR chemical shift is an indicator of the $\mathrm{Cd}^{\mathrm{II}}$ speciation as explained above and shown in Figure 3 , a linear trend can be expected if one plots the $\mathrm{p} K_{\mathrm{a} 2}$ values against the corresponding ${ }^{113} \mathrm{Cd}$ NMR chemical shifts for the different CdII complexes of the TRIL16C peptide family. Figure 4 demonstrates that this expectation is satisfied. The $\mathrm{p} K_{\mathrm{a} 2}$ value is directly correlated with the ${ }^{113} \mathrm{Cd}$ NMR chemical shifts and, thus, we have another indicator of the percentage of four- and three-coordinate $\mathrm{Cd}^{\mathrm{II}}$ species, $\mathrm{CdS}_{3} \mathrm{O}$ and $\mathrm{CdS}_{3}$. More important, this correlation provides an independent confirmation of our proposed exchange mechanism.

We next assessed the generality of this correlation by testing whether other designed peptides conformed to the same trends. Two groups of peptides were examined: 1) peptides of the TRI peptide family that contain the thiol-rich binding site in a different position from 16, and 2) GRAND and BABY peptides that are a heptad longer and shorter than TRI peptides, respectively. The $\mathrm{p} K_{\mathrm{a} 2}$ values and the corresponding ${ }^{113} \mathrm{Cd}$ NMR chemical shifts of the different GRAND, BABY and TRI peptides containing the binding site at diverse 
positions were determined and included in the plot(Figure 4). The final graphic shows that these systems satisfy the same linear trend and, therefore, we conclude that the ${ }^{113} \mathrm{Cd} \mathrm{NMR}-$ $\mathrm{p} K_{\mathrm{a} 2}$ correlation seems to stand independently of the location of the Cys site or the length of the peptide. Furthermore, we have found that the $\mathrm{Cd}^{\mathrm{II}}$ complex of the thiol derivative of the Coil-Ser peptide, $\left[\mathrm{Cd}-(\mathbf{C S L 9 C})_{3}\right]^{-}$, which has a significantly different sequence also follows this linear dependence. ${ }^{[29]}$

The strategy used in our design to obtain a fully three-coordinate $\mathrm{CdS}_{3}$ species was the replacement of Leu by the non-natural amino acid penicillamine (Pen), which increases the local bulk directly around the $\mathrm{Cd}^{\mathrm{II}}$ center. This strategy was successful and leads to peptides with large ${ }^{113} \mathrm{Cd}$ NMR chemical shifts and high $\mathrm{p} K_{\mathrm{a} 2}$ values. While the chemical shift values are a direct representation of the coordination number of the metal, one might expect that the $\mathrm{p} K_{\mathrm{a} 2}$ values could reflect both the coordination number of the metal as well as the chemical properties of the coordinated ligands. Both Cys and Pen have thiol ligands; however, Pen has two methyl groups at the $\mathrm{C}_{\beta}$ in comparison to two protons for Cys. This substitution is predicted to change the acidity of the thiol group and, thus, potentially the $\mathrm{pH}$ of $\mathrm{Cd}^{\mathrm{II}}$ sequestration. The basicities of both amino acids are similar, $\mathrm{p} K_{\mathrm{a}}$ of 8.0 for Pen vs 8.2 for Cys. ${ }^{[45,46]}$ Therefore, the higher $\mathrm{pH}$ necessary to bind $\mathrm{Cd}^{\mathrm{II}}$ to the Pen site would appear to be the result of the intrinsic coordination geometry of the binding site. To verify that this is the case, it was necessary to obtain a fully four-coordinate $\mathrm{Cd}^{\mathrm{II}}$ binding site using Pen. By analogy with TRIL12AL16C, we thought that opening a hole above the Pen layer might generate the desired four-coordinate $\mathrm{Cd}^{\mathrm{II}}$ and answer this question. $\mathrm{A}^{113} \mathrm{Cd} \mathrm{NMR}$ chemical shift of $583 \mathrm{ppm}$ was observed at $\mathrm{pH} 8.5$ for the complex

[Cd(TRIL12AL16Pen) $\left.{ }_{3}\right]^{-}$. Based on the ${ }^{113} \mathrm{Cd}$ NMR_- ${ }^{111 \mathrm{~m}} \mathrm{Cd}$ PAC correlation (Figure 3), this result indicates that we have obtained a four-coordinate $\mathrm{CdS}_{3} \mathrm{O}$ species using Pen as a ligand. Conclusive proof for this assignment comes from the ${ }^{111 \mathrm{~m}} \mathrm{Cd}$ PAC data since a single NQI with a $\omega_{0}$ value of $0.339 \mathrm{rad} \mathrm{ns}^{-1}$ was obtained. The results obtained for [Cd(TRIL12AL16Pen) $\left.]_{3}\right]^{-}$fit nicely in the ${ }^{113} \mathrm{Cd}$ NMR $-{ }^{111 \mathrm{~m}} \mathrm{Cd}$ PAC correlation (see Figure 3). This $\mathrm{Cd}^{\mathrm{II}}$ complex has a higher value of $\eta(0.36)$ in comparison with the other two complexes containing a $100 \% \mathrm{CdS}_{3} \mathrm{O},\left[\mathrm{Cd}(\text { TRIL12AL16C) })_{3}\right]^{-}(\eta=0.141)$ and $\left.[\text { Cd(TRIL9AL16C })_{3}\right]^{-}(\eta=0.19)$. The parameter $\eta$ is the asymmetry parameter and gives information regarding the symmetry of the $\mathrm{Cd}^{\mathrm{II}}$ center. Its value ranges from 0 to 1 , where 0 represents pure axial symmetry. A higher value of $\eta$ is indicative of a higher degree of distortion in the binding site and, thus, a larger deviation from a tetrahedral geometry. This higher distortion of the four-coordinate Pen site is most likely due to the presence of the methyl groups at the $\mathrm{C}_{\beta}$ that introduces local hindrance around the thiol donors.

We next determined the $\mathrm{pH}$ dependence of $\mathrm{Cd}^{\mathrm{II}}$ binding to TRIL12AL16Pen. As shown in Figure 2 (open circles) the $\mathrm{pH}$ profile obtained reveals that the coordination geometry, and not the ligand basicity, is the factor controlling the site acidity. The $\mathrm{p} K_{\mathrm{a} 2}$ value drops from 15.8 to 12.7 in moving from a three-coordinate to a four-coordinate Pen metal-binding site. Consistent with these observations, a $\mathrm{p} K_{\mathrm{a} 2}$ of 15.1 is obtained for $\mathrm{Cd}^{\mathrm{II}}$ binding to

TRIL12L $\mathbf{D}_{\mathbf{D}} \mathbf{L 1 6 C}$, a peptide that binds $\mathrm{Cd}^{\mathrm{II}}$ as a fully $100 \% \mathrm{CdS}_{3}$ and contains Cys as a coordinating ligand. ${ }^{[44]}$

Figure 4 demonstrates that all four-coordinate sites, independently of the nature of the thiol group (Cys or Pen), bind $\mathrm{Cd}^{\mathrm{II}}$ fully under lower $\mathrm{pH}$ conditions than do the three-coordinate sites. Another feature is apparent upon closer examination of this correlation. The $\mathrm{p} K_{\mathrm{a} 2}$ values obtained for peptides that bind $\mathrm{Cd}^{\mathrm{II}}$ exclusively as three-coordinate $\mathrm{CdS}_{3}$ species have little variation, whereas those peptides sequestering $\mathrm{Cd}^{\mathrm{II}}$ as a four-coordinate $\mathrm{CdS}_{3} \mathrm{O}$ species exhibit a wide range for the $\mathrm{p} K_{\mathrm{a} 2}$ values (11.3 to 13.3). These data indicate that moving from TRI to GRAND peptides or by introducing double substitutions, the $\mathrm{pH}$ dependence of $\mathrm{Cd}^{\mathrm{II}}$ binding to the three-coordinate site is essentially unaffected, while these 
modifications significantly perturb the four-coordinate site. This variation most likely is a reflection of different self-association affinities and $\mathrm{pH}$-dependent aggregation state preferences of the peptides themselves. For example, the GRAND peptides show a higher self-association affinity than TRI peptides, $\approx 5 \mathrm{kcal} \mathrm{mol}^{-1}$ per coiled coil aggregate. On the other hand, the disruption of a Leu layer by smaller nonpolar amino acids, such as Val and Ala, can destabilize the final coiled coil up to $6-7 \mathrm{kcal} \mathrm{mol}^{-1}$, reflecting poorer hydrophobic packing. ${ }^{[26]}$ The greater stability of the GRAND peptides result in the formation of threestranded coiled coils at $\mathrm{pH}$ conditions lower than 6.0. This enhanced aggregate stability provides a scaffold which can complex $\mathrm{Cd}^{\mathrm{II}}$ at lower $\mathrm{pH}$ values than the corresponding TRI peptides. At the other extreme, coiled coils that have been destabilized by disrupting the core packing require higher $\mathrm{pH}$ to form the assembly which is necessary to sequester the metal properly. In support of this model, we observe that an increase in the concentration of the TRI peptide with respect to the amount of $\mathrm{Cd}^{\mathrm{II}}$ shifts the $\mathrm{pH}$ profile for formation of the complex to lower $\mathrm{pH}$ values. This suggests that the formation/stabilization of the fourcoordinate $\mathrm{Cd}^{\mathrm{II}}$ may be achieved at more acidic $\mathrm{pH}$ values than those observed here by increasing the self-association energy of the three-stranded coiled coil. This explanation also rationalizes the small variance in $\mathrm{p} K_{\mathrm{a} 2}$ values for three-coordinate $\mathrm{CdS}_{3}$ peptides containing penicillamine. The Pen substitution stabilizes the three-stranded coiled coil significantly and, since high $\mathrm{pH}$ is required to form the trigonal structure, these peptides all exhibit high self-affinity under these conditions. The data indicate that the lower limit for the $\mathrm{p} K_{\mathrm{a} 2}$ value of this type of four-coordinate site is determined in our systems by the actual formation of the binding site. The data included in the supporting information corroborates all these observations.

This behavior is very different from that observed for the $\mathrm{Hg}^{\mathrm{II}}$ complexes of the TRI peptide family where the formation of a three-coordinate thiolate $\mathrm{Hg}^{\mathrm{II}}$ center does not depend on the stability of the coiled coil. ${ }^{[47-49]}$ In this case, there are two relevant equilibria. The first is the conversion of a two-stranded coiled coil to a three-stranded coiled coil aggregate. This equilibrium appears to be metal independent having a $\mathrm{p} K_{\mathrm{a}}$ for TRI, with and without $\mathrm{Hg}^{\mathrm{II}}$, of approximately 5.5. The second equilibrium is between a three-stranded coiled coil containing linear $\mathrm{Hg}^{\mathrm{II}}$ as $\mathrm{HgS}_{2}$ and the trigonal planar $\mathrm{Hg}^{\mathrm{II}}$ species $\mathrm{HgS}_{3}$. As long as one examines peptides that have Cys substitution in the "a" heptad position, one observes the conversion of $\mathrm{Hg}$-(peptide) $)_{2}$ (peptide- $\mathrm{H}$ ) to $\mathrm{Hg}$ (peptide) ${ }_{3}{ }^{-}$plus loss of a proton with a $\mathrm{p} K_{\mathrm{a}}=$ 7.7. This is true regardless of whether the peptide used is TRIL16C, TRIL9C, BABYL9C or GRANDL9C. ${ }^{[47,48]}$

At this point, we have obtained two important correlations between $\mathrm{CdS}_{3} \mathrm{O}$ centers $\left(\omega_{0} \approx\right.$ $\left.0.34 \mathrm{rad} \mathrm{ns}^{-1}\right)$ and $\mathrm{CdS}_{3}$ centers $\left(\omega_{0} \approx 0.45 \mathrm{rad} \mathrm{ns}^{-1}\right)$ that allow the determination, based only in the ${ }^{113} \mathrm{Cd}$ NMR chemical shift, of the percentage of four-coordinate $\mathrm{CdS}_{3} \mathrm{O}$ and three-coordinate $\mathrm{CdS}_{3}$ species (Figure 3 ) and the $\mathrm{pH}$ required for full $\mathrm{Cd}^{\mathrm{II}}$ binding (Figure 4). Both correlations track the ratio of both species in solution. Often one sees quoted in references that a specific coordination geometry (e.g., $\mathrm{CdS}_{3} \mathrm{O}$ ) has a broad ${ }^{113} \mathrm{Cd} \mathrm{NMR}$ chemical shift range without an explanation for the factors that cause the large variation. To our knowledge, this study provides the first systematic explanation for why the ${ }^{113} \mathrm{Cd} \mathrm{NMR}$ chemical shift range can vary over what might be perceived to be $125 \mathrm{ppm}$. Furthermore, we have demonstrated for the first time that ${ }^{113} \mathrm{Cd}$ NMR can be used as a highly sensitive probe of the equilibrium contributions of two rapidly interchanging protein bound species when the two limiting species have been clearly identified. The next question that we must ask is how general this correlation is.

To address this point we must recognize that a four-coordinate $\mathrm{Cd}^{\mathrm{II}}$ with three endogenous sulfur ligands can vary its structure in several ways within our designed peptides. First, is the issue of metal binding to "a" versus "d" type sites. Both $\mathrm{Cd}^{\mathrm{II}}$ and $\mathrm{Hg}^{\mathrm{II}}$ show, for 
example, different $\mathrm{p} K_{\mathrm{a}}$ values for formation of $\mathrm{MS}_{3}$ species when the site is in an "a" versus "d" position. Modelling studies suggest that the orientation of Cys in these two sites is markedly different with Cys sulfurs in an "a" site positioned towards the central axis of the helix whereas "d" sites orient the Cys towards the helical interfaces. Second, the position of the metal binding site may be displaced either towards the $\mathrm{N}$ - or C-terminal ends of the peptides. As an example of this discrepancy we can consider our recent crystallographic study of As-(CSL9C) ${ }_{3}$, an analogous peptidic system to TRI, that has provided the first Xray structure of $\mathrm{As}^{\mathrm{III}}$ coordinated to three Cys residues in a protein environment (Figure $5 \mathrm{~A}) .{ }^{[50]}$ The $\mathrm{As}{ }^{\mathrm{III}}$ was found to be in a trigonal pyramidal geometry with As-S bond lengths $(2.28 \pm 0.05 \AA)$ and S-As-S angles $\left(92^{\circ}\right)$ in good agreement with small molecule complexes and the EXAFS distances previously determined for As ${ }^{\mathrm{III}}$ coordination to TRIL12C,

TRIL16C, ArsR and ArsD ${ }^{[51-54]}$ Most important, the As ${ }^{\mathrm{III}}$ ion was found to be coordinated below the plane of the $\beta$-methylene protons of Cys in an endo conformation and not in an exo conformation capping the Cys residues as was previously assumed by most workers in this field. ${ }^{[55]}$ On the other hand, $\mathrm{Pb}^{\mathrm{II}}$, which also prefers a trigonal pyramidal thiol-rich binding site, shows an exo configuration being coordinated above the thiolate plane when bound to the protein aminolevulinic acid dehydratase (Figure 5B). ${ }^{[56]}$ This binding mode is consistent with the larger size of $\mathrm{Pb}^{\mathrm{II}}$ in comparison to $\mathrm{As}^{\mathrm{III}}$, with typical $\mathrm{Pb}^{\mathrm{II}}-\mathrm{S}$ distances of 2.62-2.67 $\AA$ for three-coordinate $\mathrm{PbS}_{3}$ structures. ${ }^{[33,57-60]}$ Consistent with these data, our EXAFS spectroscopic studies demonstrate that $\mathrm{Pb}^{\mathrm{II}}$ binds to TRIL16C and TRIL12C peptides as a $\mathrm{PbS}_{3}$ structure with $\mathrm{Pb}^{\mathrm{II}}-\mathrm{S}$ distances of $2.63 \AA^{\left[{ }^{[27]}\right.} \mathrm{Cd}^{\mathrm{II}}$ is intermediate in size between $\mathrm{As}^{\mathrm{III}}$ and $\mathrm{Pb}^{\mathrm{II}}$ and has the potential to bind to peptides in either the endo or exo conformations as is demonstrated in Figure 5C and D. However, unlike both $\mathrm{As}^{\mathrm{III}}$ and $\mathrm{Pb}^{\mathrm{II}}$ which contain stereochemically active lone pairs filling the fourth coordination sites, $\mathrm{Cd}^{\mathrm{II}}$ can bind a water molecule in this fourth position.

From the ${ }^{113} \mathrm{Cd}$ NMR and ${ }^{111 \mathrm{~m}} \mathrm{Cd}$ PAC spectroscopic data we know that the TRIL16C peptide binds $\mathrm{Cd}^{\mathrm{II}}$ as a mixture of four- and three-coordinate $\mathrm{Cd}^{\mathrm{II}}$ species $\left(\mathrm{CdS}_{3} \mathrm{O}\right.$ and $\left.\mathrm{CdS}_{3}\right) .{ }^{[25]}$ Certainly, the $\mathrm{CdS}_{3}$ polyhedron is trigonal planar; however, one must consider whether the $\mathrm{Cd}^{\mathrm{II}}$ in the $\mathrm{CdS}_{3} \mathrm{O}$ structure is in an exo or endo conformation. The replacement of the Leu layer above the metal thiol-rich binding site by Ala has proven sufficient to generate two peptides, TRIL12AL16C ${ }^{[30]}$ and TRIL12AL16Pen, capable of binding Cd ${ }^{\mathrm{II}}$ solely with a four-coordinate $\mathrm{CdS}_{3} \mathrm{O}$ distorted tetrahedral geometry. This mutation should generate sufficient space above the thiol ligands to allow water access to the hydrophobic interior. This observation would suggest that $\mathrm{Cd}^{\mathrm{II}}$ should bind to these sites in a way that resembles most closely the $\mathrm{Pb}^{\mathrm{II}}$ exo conformation rather than the $\mathrm{As}{ }^{\mathrm{III}}$ endo. Such an assignment is consistent with an NMR structure of $\mathrm{Cd}^{\mathrm{II}}$ bound to the HIV-I integrase H12C mutant. ${ }^{[61]}$ The observation that when the second Leu layer above the Cys is replaced with Ala (TRIL9AL16C) the peptide binds $\mathrm{Cd}^{\mathrm{II}}$ as solely a $\mathrm{CdS}_{3} \mathrm{O}$ species, whereas the equivalent mutation below the Cys layer (TRIL16CL23A) has essentially no effect on the ratio of $\mathrm{CdS}_{3} \mathrm{O}$ and $\mathrm{CdS}_{3}$ as compared to TRIL16C, further supports an exo conformation. Our best interpretation of these results is that opening a hole at position 9 could affect the hydrophobic packing of the Leu at position 12 allowing the entrance of water to the hydrophobic interior and thus its coordination to $\mathrm{Cd}^{\mathrm{II}}$. It should be noted that these three peptides (TRIL12AL16C, TRIL12AL16Pen and TRIL9AL16C) all exhibit PAC spectra with $\omega_{0} \approx 0.34 \mathrm{rad} \mathrm{ns}^{-1}$. In fact, every peptide complex reported in the correlations of Figure 3 and 4 which contain a $\mathrm{CdS}_{3} \mathrm{O}$ species also shows $\omega_{0} \sim 0.34 \mathrm{rad} \mathrm{ns}^{-1}$. Thus, we conclude that the correlations that we have discovered are directly applicable to understanding equilibria between $\mathrm{CdS}_{3}$ and $\mathrm{CdS}_{3} \mathrm{O}$ species bound in "a" site peptides with an exo metal conformation.

One might then ask what are the properties of $\mathrm{CdS}_{3} \mathrm{O}$ sites oriented in an endo conformation or bound within a "d" site environment. Unfortunately, sufficient data do not yet exist for 
such constructs to evaluate these possibilities fully; however, we have been able to isolate one system that may begin to address one of these questions. The peptide TRIL16CL19A engineers a water-binding pocket below the metal binding site which might induce a shift in metal environment to the endo conformation. The ${ }^{113} \mathrm{Cd}$ NMR chemical shift for $\left[\mathrm{Cd}(\text { TRIL16CL19A })_{3}\right]^{-}$is $605 \mathrm{ppm}$ and the PAC spectrum indicates that this peptide contains $100 \% \mathrm{CdS}_{3} \mathrm{O}$ but now with an $\omega_{0}=0.274 \mathrm{rad} \mathrm{ns}^{-1}$. This chemical shift value and composition is inconsistent with the trend found in Figure 3. Furthermore, the $\mathrm{p} K_{\mathrm{a} 2}$ for this peptide is 11.2 a value which again is inconsistent with the 16 points reported in Figure 4. The tempting conclusion is that $\mathrm{CdS}_{3} \mathrm{O}$ sites with $\omega_{0}>0.33 \mathrm{rad} \mathrm{ns}^{-1}$ correspond to exo conformations of the $\mathrm{Cd}^{\mathrm{II}}$ whereas $\omega_{0}<0.28 \mathrm{rad} \mathrm{ns}^{-1}$ may indicate the endo conformers. Furthermore, a change in the exo versus endo conformation may lead to different trend lines for the scaling of the $\mathrm{CdS}_{3} \mathrm{O} / \mathrm{CdS}_{3}$ ratio with NMR and the acidity of the corresponding metal binding site. These intriguing possibilities must await further study to be confirmed; however, the concepts presented by these data raise interesting general questions for $\mathrm{Cd}^{\mathrm{II}}$ binding to proteins, the use of $\mathrm{Cd}^{\mathrm{II}}$ as a probe for $\mathrm{Zn}^{\mathrm{II}}$ and the interpretation of ${ }^{113} \mathrm{Cd} \mathrm{NMR}$ for $\mathrm{Cd}^{\mathrm{II}}$-substituted $\mathrm{Zn}^{\mathrm{II}}$ sites in biology.

The pioneers investigating $\mathrm{Cd}^{\mathrm{II}}$ binding to proteins, especially as a spectroscopically amenable substitute for $\mathrm{Zn}^{\mathrm{II}}$, were confined to those systems that became available and which may or may not have been structurally characterized. This meant that broad chemical shift ranges could be mapped; however, detailed questions relating to specific geometries or the impact of protein dynamics were difficult to explore. In this article, we have

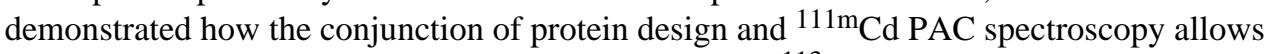
for a more refined level of understanding for biological ${ }^{113} \mathrm{Cd} \mathrm{NMR}$. The systematic variation of protein constructs using de novo designed peptides allows the control of most structural variables for a metalloprotein. Thus, one may make a subtle sequence change that perturbs a highly defined metal chromophore in an interpretable manner. In this way it becomes straightforward to prepare a suite of proteins that can be used to interrogate defined physical properties of interest (e.g., ${ }^{113} \mathrm{Cd}$ NMR shift or $\mathrm{p} K_{\mathrm{a}}$ ). PAC spectroscopy provides a faster timescale to interrogate the metal center. In this case, it revealed that what may have been interpreted as a single species based on ${ }^{113} \mathrm{Cd}$ NMR was in fact an equilibrium between two fast exchanging species. Furthermore, by extracting the NQI parameters, one may obtain useful information about the metal site such as whether a pseudotetrahedral metal binds in an endo or an exo conformation. Therefore, one is now able to systematically vary the properties of well defined binding sites so that correlations as presented here may be deduced.

The first of these correlations provides decisive proof for the $\mathrm{CdS}_{3}$ to $\mathrm{CdS}_{3} \mathrm{O}$ equilibrium model and demonstrates that one may use ${ }^{113} \mathrm{Cd}$ NMR as an accurate and convenient method to assess the ratios of these two species. Moreover, it illustrates that $\mathrm{Cd}^{\mathrm{II}}$ bound to a protein with fast ligand exchange can exhibit intermediary physical properties between the two exchanging species. Certainly this is true for the coalesced ${ }^{113} \mathrm{Cd}$ NMR chemical shift, but more importantly, the $\mathrm{pH}$ at which the complex converts to having all sulfurs bound to the metal (either as $\mathrm{CdS}_{3} \mathrm{O}$ or $\mathrm{CdS}_{3}$ ) is dependent upon the ratio of these two components. For this system, if one knows the ${ }^{113} \mathrm{Cd}$ chemical shift, then one can predict with a high degree of accuracy the $\mathrm{p} K_{\mathrm{a} 2}$ for complex formation. Since the binding affinity of the metal to the protein is enhanced when all three sulfurs bind, this suggests that the thermodynamically more stable constructs will be enriched in the $\mathrm{CdS}_{3} \mathrm{O}$ component. $\mathrm{Cd}^{\mathrm{II}}$ binding to heterochromic polypeptides exhibits just this specificity and selectivity. ${ }^{[31]}$

To date, there has been the tendency to assign a ${ }^{113} \mathrm{Cd}$ chemical shift to a single, specific coordination structure and to support this assignment by indicating that the chemical shift value falls within a broad range of shifts consistent with the assigned structure. Our studies 
indicate that one should consider a dynamic model for metal binding which may include more than one species. Furthermore, these observations suggest that a protein may be able to fine tune the affinity of $\mathrm{Cd}^{\mathrm{II}}$ binding by developing a metal site that controls the ratio of $\mathrm{CdS}_{3} \mathrm{O}$ to $\mathrm{CdS}_{3}$ (or in principle two other species of different affinity which are in fast exchange).

One example where such a process may be operable is the SmtB type metalloregulatory protein CadC. ${ }^{[20]}$ Site-directed mutagenesis and Cd EXAFS spectroscopy support the assignment of the $\mathrm{Cd}^{\mathrm{II}}$ binding site as $\mathrm{CdS}_{4}$. The ${ }^{113} \mathrm{Cd}$ chemical shift is $625 \mathrm{ppm}$, a value that is comfortably within literature values for $\mathrm{CdS}_{4}$ (typically reported as 590 to 750 ppm). ${ }^{[12,15]}$ However, it is surprising that the $\mathrm{CdS}_{4}$ range is so large and overlaps so significantly with $\mathrm{CdS}_{3}$-type complexes. Typically, the addition of each sulphur to the $\mathrm{Cd}^{\mathrm{II}}$ coordination sphere causes a significant downfield shift, yet $\mathrm{CdS}_{4}$ overlaps $\mathrm{CdS}_{3}$ shifts for over half their range (from 590 to $700 \mathrm{ppm}$ ). We have noticed that the pure species $\mathrm{CdS}_{3}$ or $\mathrm{CdS}_{3} \mathrm{O}$ have relatively narrow chemical shift ranges. With pure $\mathrm{CdS}_{3}$ species, we observe a range of chemical shifts of $\approx 25 \mathrm{ppm}$ (from 675 to $700 \mathrm{ppm}$ ). The same can be said for $\mathrm{CdS}_{3} \mathrm{O}$ which appears to span 570-600 ppm. The $125 \mathrm{ppm}$ breadth that occurs is a result of the equilibrium between these two species. It is tempting to suggest that the even broader range reported for $\mathrm{CdS}_{4}(160 \mathrm{ppm})$ could also be a consequence of mixed sites. If this reasoning is correct, then a more appropriate value for a pure $\mathrm{CdS}_{4}$ species would likely be closer to $750 \mathrm{ppm}$, with a lower limit of $\approx 720 \mathrm{ppm}$. If a pure $\mathrm{CdS}_{4}$ in a protein environment truly has this chemical shift range, how then could one explain the $625 \mathrm{ppm}$ resonance of CadC? The simplest explanation would be that $\mathrm{Cd}^{\mathrm{II}}$ might bind as a mixture of $\mathrm{CdS}_{4}$ and $\mathrm{CdS}_{3} \mathrm{O}$, with water as the fourth ligand. This makes the CadC system an ideal target for PAC studies to test this hypothesis.

The situation becomes even more interesting when considering proteins designed to bind $\mathrm{Zn}^{\mathrm{II}}$. Important examples for our studies are the $\mathrm{ZnS}_{3} \mathrm{O}$ site of hepatitis $\mathrm{C}$ virus NS3 proteinase and an $\mathrm{HIV}-1$ integrase mutant which also forms a $\mathrm{ZnS}_{3} \mathrm{O}$ structure. ${ }^{[22,61]}$ While it has become commonplace to substitute $\mathrm{Cd}^{\mathrm{II}}$ for $\mathrm{Zn}^{\mathrm{II}}$ in proteins like these, the replacement is not completely benign. $\mathrm{Cd}^{\mathrm{II}}$ is larger and has longer bond lengths than $\mathrm{Zn}^{\mathrm{II}}$ (e.g., for $\mathrm{CdS}_{3} \mathrm{O}$ the $\mathrm{Cd}-\mathrm{S}$ bond is approximately $2.54 \AA$ whereas the corresponding $\mathrm{Zn}^{\mathrm{II}}$ distance is $2.32 \AA) .{ }^{[42,62]}$ Furthermore, $\mathrm{Cd}^{\mathrm{II}}$ is somewhat softer than $\mathrm{Zn}^{\mathrm{II}}$ and prone to form higher coordination number complexes. In the case of substitution into an identical protein environment the most likely concern is size. Size can shift the preference of a metal from an exo to an endo conformation as has been reported for As(CSL9C $)_{3}{ }^{[50]}$ The differential size may also restrict the ability for an exogenous ligand such as water to bind to the metal. Thus, in metal-binding sites such as those found in the TRI peptides, steric constraints appear to favour the formation of a significant percentage of $\mathrm{CdS}_{3}$ centers (e.g., TRIL16C). The $0.2 \AA$ shorter bond lengths of $\mathrm{ZnS}_{3} \mathrm{O}$ should not be as influenced by this steric constraint, suggesting that $\mathrm{Zn}^{\mathrm{II}}$ might bind to all, or most, of these designed peptides as a four coordinate complex with bound water. What these data would suggest is that in cases where an equilibrium process is in effect for $\mathrm{Cd}^{\mathrm{II}}$ in a protein, cadmium substitution may not provide fully appropriate information about the zinc environment.

We have proposed a number of tantalizing questions which may have profound impact for understanding biological cadmium coordination chemistry, the interpretation of ${ }^{113} \mathrm{Cd} \mathrm{NMR}$ spectra and the application of $\mathrm{Cd}^{\mathrm{II}}$ substitution as a reporter for the highly prevalent $\mathrm{Zn}^{\mathrm{II}}$ class of metalloproteins. However, there are some caveats that must be considered at this stage. While we have a reasonable explanation for the large chemical shift range for at least one coordination environment (ostensibly $\mathrm{CdS}_{3} \mathrm{O}$ ) and have enumerated several factors that contribute to the chemical shift variation, our correlation is, in fact, limited to $\mathrm{CdS}_{3}$ trigonal planar to $\mathrm{CdS}_{3} \mathrm{O}$ pseudotetrahedral structures found in "a" type sites, presumably with the 
metal in an exoconfiguration. One might expect some variation to our reported trends if the metal is located in "d" sites or in an endo conformation. Furthermore, other factors such as the change in orientation of thiolate donors on converting from parallel to antiparallel helices, and hydrogen bonding could further broaden the chemical shift ranges discussed here. Because of the importance of zinc metalloproteins and the applications of $\mathrm{Cd}^{\mathrm{II}}$ for understanding the metal center structure and function, it is clear that additional studies addressing each of these points is essential. We have shown how de novo designed peptides can be powerful vehicles to examine these important issues. We expect that future studies with variants of these peptides will further elucidate this fascinating and important problem.

\section{Experimental Section}

\section{Peptide synthesis and purification}

The TRI peptides and derivatives (see Table 1 for sequence nomenclature) were synthesized on an Applied Biosystems 433 A peptide synthesizer using standard F-moc protocols, ${ }^{[63]}$ and purified and characterized as described previously. ${ }^{[4]}$

\section{PAC spectroscopy}

All perturbed angular correlation (PAC) experiments were performed with a setup using six detectors and a temperature of $1 \pm 2{ }^{\circ} \mathrm{C}$, which was controlled by a Peltier element. The radioactive cadmium was produced on the day of the experiment at the University Hospital cyclotron in Copenhagen and extracted as described previously, ${ }^{[64]}$ except for the HPLC separation of zinc and cadmium which was omitted. This procedure may lead to zinc contamination of the sample, but the level of contamination should not interfere with the experiment. The ${ }^{111 \mathrm{~m} C d}$ solution (10-40 $\mu \mathrm{L}$ ) was mixed with nonradioactive cadmium acetate and TRIS buffer. The peptide, dissolved in ion-exchanged water, was then added and the sample was left to equilibrate for 10 min to allow for metal binding. Finally, sucrose was added to produce a $55 \%$ w/w solution. The $\mathrm{pH}$ of the solution was adjusted with $\mathrm{H}_{2} \mathrm{SO}_{4}$ or $\mathrm{KOH}$. In order to avoid chloride contamination, a small volume of sample was removed from the solution and the $\mathrm{pH}$ measured. The $\mathrm{pH}$ reported in Table 2 was measured at room temperature the following day and corrected to the $\mathrm{pH}$ at $1{ }^{\circ} \mathrm{C}$ as follows. The $\mathrm{pH}$ of solutions buffered by TRIS is temperature dependent; therefore the $\mathrm{pH}$ of the solutions at 1 ${ }^{\circ} \mathrm{C}$ was calculated using the following equation $\mathrm{pH}\left(1{ }^{\circ} \mathrm{C}\right) 0.964\left[\mathrm{pH}\left(25^{\circ} \mathrm{C}\right)\right]+0.86 .{ }^{[65]}$ The samples were either used immediately after preparation or left on ice for up to $2 \mathrm{~h}$ until the measurement was started. All buffers were purged with Ar and treated so as to lower metal contamination. The final volume of the samples ranged between 0.05 and $0.5 \mathrm{~mL}$ with concentrations of $300 \mu_{\mathrm{m}}$ peptide, $20 \mathrm{~m}_{\mathrm{M}}$ TRIS buffer and a $\mathrm{Cd}$ II/peptide ratio of 1:12. All fits were carried out with 400 data points, disregarding the $3-5$ first points due to systematic errors in these. For the TRIL12AL16Pen peptide, 300 points were used in the fit.

Each nuclear quadrupole interaction (NQI) was modelled using a separate set of parameters that includes $\omega_{0}, \eta, \Delta \omega_{0} / \omega_{0}, 1 / \tau_{\mathrm{c}}$ and A. The parameter $\omega_{0}\left[\omega_{0}=12 \pi\left|e Q V_{z Z}\right| /(40 \mathrm{~h})\right.$, where $Q$ is the nuclear electric quadrupole moment and $V_{z Z}$ is the numerically largest eigenvalue of the electric field gradient tensor] is associated with the strength of the interaction between the surrounding electronic environment and the Cd nucleus, $\eta$ is the socalled asymmetry parameter which is 0 in an axially symmetric complex and has a maximal value of $1 ; \Delta \omega_{0} / \omega_{0}$ describes static structural variations from one $\mathrm{Cd}^{\mathrm{II}}$ site to the next, and is as such a measure of the structural variability; $\tau_{\mathrm{c}}$ is the rotational correlation time; and $\mathrm{A}$ is the amplitude of the signal (see ref. [25] for a more detailed description). The parameters fitted to the PAC data are presented in Table 2. The percentage of each species reported in Table 3 were calculated based on the $A$ value. 


\section{${ }^{113}$ Cd NMR spectroscopy}

All the spectra were collected at room temperature on a Varian Inova 500 spectrometer (110.92 $\mathrm{MHz}$ for ${ }^{113} \mathrm{Cd}$ ) equipped with a $5 \mathrm{~mm}$ broadband probe. ${ }^{113} \mathrm{Cd}$ NMR spectra were externally referenced to a $0.1{ }_{\mathrm{m}} \mathrm{Cd}\left(\mathrm{ClO}_{4}\right)_{2}$ solution in $\mathrm{D}_{2} \mathrm{O}$. A spectral width of $847 \mathrm{ppm}(93$ $897 \mathrm{~Hz}$ ) was sampled using a $5.0 \mu \mathrm{s} 90^{\circ}$ pulse and $0.05 \mathrm{~s}$ acquisition time with no delay between scans. Samples were prepared under a flow of argon or nitrogen by dissolving 30 $35 \mathrm{mg}$ of the lyophilized and degassed peptides in $450-500 \mu \mathrm{L} 15 \% \mathrm{D}_{2} \mathrm{O}$ solution. The peptide concentrations were determined by using either the Ellman's ${ }^{[66]}$ or $4,4^{\prime}$-dipyridyl disulphide tests, ${ }^{[67]}$ and the concentrations range from 12 to $18 \mathrm{~m}_{\mathrm{m}}$ peptide, which corresponds to 4-6 mм three-stranded coiled coil. The final samples were prepared by the addition of the appropriate amount of $250 \mathrm{~mm}_{\mathrm{M}}{ }^{113} \mathrm{Cd}\left(\mathrm{NO}_{3}\right)_{2}$ solution (prepared from $95 \%$ isotopically enriched ${ }^{113} \mathrm{CdO}$ obtained from Oak Ridge National Laboratory) and the adjustment of the $\mathrm{pH}$ with $\mathrm{KOH}$ or $\mathrm{HCl}$ solutions. The final $\mathrm{pH}$ value for each peptide was chosen based on its $\mathrm{pH}$ titration curves. This $\mathrm{pH}$ value correspond to the fully formation of the $\mathrm{Cd}^{\mathrm{II}}$ complex. An Argon or Nitrogen atmosphere was maintained when possible but the samples came in contact with $\mathrm{O}_{2}$ while the $\mathrm{pH}$ was adjusted. The actual final concentrations for each experiment are indicated in the text and the Figure captions. The data were analyzed using the software MestRe-C. ${ }^{[68]}$ All free induction decays (FID's) were zero filled to double the original points and were processed by application of $50 \mathrm{~Hz}$ line broadening prior to Fourier transformation.

\section{UV/Vis spectroscopy}

All the UV/Vis $\mathrm{pH}$ titration experiments were carried out at room temperature on an Ocean Optics SD 2000 fiber optic spectrometer. Fresh stock solutions of the purified peptides were prepared for each experiment using doubly distilled water and were purged with argon to minimize the chances of oxidation. The peptide concentration was determined as described in the ${ }^{113} \mathrm{Cd}$ NMR section. ${ }^{[66,67]} \mathrm{pH}$ Titrations were performed by adding small aliquots of $\mathrm{KOH}$ ( $1 \mathrm{~m}_{\mathrm{M}}$ to $1 \mathrm{~m}$ stock solutions) to unbuffered solutions containing $\mathrm{CdCl}_{2}$ salt $\left(20 \mu_{\mathrm{M}}\right)$ and peptide $\left(60-120 \mu_{\mathrm{M}}\right)$. All the doubly distilled water used in these experiments was bubbled with $\mathrm{Ar}$ before addition of $\mathrm{CdCl}_{2}$ and peptide. The change in $\mathrm{pH}$ was monitored using an Accumet gel-filled pencil-thin $\mathrm{Ag} / \mathrm{AgCl}$ single-junction electrode with an Orion Research digital $\mathrm{pH}$ millivolt meter 611. In all cases, equilibration time was allowed before reading the final $\mathrm{pH}$ and it was found that binding of $\mathrm{Cd}^{\mathrm{II}}$ to TRIL16Pen, TRIL12VL16Pen and GrandL16Pen was slower than binding the other peptides. To verify the reversibility of the process, reverse titrations were carried out subsequently in all the experiments by adding small aliquots of $1 \mathrm{~m}_{\mathrm{m}}$ to $1 \mathrm{~m}$ solutions of $\mathrm{HCl}$. The $\mathrm{pH}$-dependent absorption spectra were fit using the same models and procedures as those used in our previous studies. ${ }^{\text {[27, 29] }}$ Specifically, the experimental data were analyzed by non-linear least square fitting to the following equation:

$$
\mathrm{Cd}\left[(\text { peptide }-\mathrm{H})_{2}(\text { peptide })\right]^{+}=\mathrm{Cd}(\text { peptide })_{3}{ }^{-}+2 \mathrm{H}^{+} \mathrm{Abs}=\left(c[\mathrm{M}]_{\mathrm{t}} * \Delta \varepsilon\right) /\left(10^{\left.\left(\mathrm{p} K_{\mathrm{a} 2}-2 \mathrm{pH}\right)_{+1}\right)}\right.
$$

where Abs is the observed absorbance after addition of $\mathrm{KOH}, c[\mathrm{M}]_{\mathrm{t}}$ is the total metal concentration, $\Delta \varepsilon$ is the extinction coefficient of the metal complex, and $\mathrm{p} K_{\mathrm{a} 2}$ the acidity constant for the simultaneous release of two protons. The data were also fit using an extended model including additional species in solution (see Supporting Information for a full description).

\section{Acknowledgments}

V.L.P. thanks the National Institute of Health for support of this research (R01 ES0 12236), O.I. thanks the Margaret and Herman Sokol Foundation for a Postdoctoral Award and L.H. thanks The Danish Natural Science Research Council for support. 


\section{References}

1. Vallee BL, Auld DS. Biochemistry. 1990; 29:5647-5659. [PubMed: 2200508]

2. Lipscomb WN, Sträter N. Chem. Rev. 1996; 96:2375-2434. [PubMed: 11848831]

3. Coleman JE. Curr. Opin. Chem. Biol. 1998; 2:222-234. [PubMed: 9667939]

4. Berg JM, Shi Y. Science. 1996; 271:1081-1085. [PubMed: 8599083]

5. Klug A. J. Mol. Biol. 1999; 293:215-218. [PubMed: 10529348]

6. McCall KA, Huang CC, Fierke CA. J. Nutr. 2000; 130:1437S-1446S. [PubMed: 10801957]

7. Tobin DA, Pickett JS, Hartman HL, Fierke CA, Penner-Hahn JE. J. Am. Chem. Soc. 2003; 125:9962-9969. [PubMed: 12914459]

8. Sousa SF, Fernandes PA, Ramos MJ. J. Biol. Inorg. Chem. 2005; 10:3-10. [PubMed: 15611883]

9. Myers LC, Terranova MP, Nash HM, Markus MA, Verdine GL. Biochemistry. 1992; 31:45414547. [PubMed: 1581309]

10. Penner-Hahn J. Curr. Opin. Chem. Biol. 2007; 11:166-171. [PubMed: 17376731]

11. Andreini C, Banchi L, Bertini I, Rosato A. J. Proteome Res. 2006; 5:196-201. [PubMed: 16396512]

12. Ecoleman J. Methods Enzymol. 1993; 227:16-43. [PubMed: 8255225]

13. Maret W, Vallee BL. Methods Enzymol. 1993; 226:52-71. [PubMed: 8277880]

14. Summers MF. Coord. Chem. Rev. 1988; 86:43-134.

15. Öz G, Pountney DL, Armitage IM. Biochem. Cell Biol. 1998; 76:223-243. [PubMed: 9923691]

16. Hemmingsen L, Nárcisz K, Danielsen E. Chem. Rev. 2004; 104:4027-4061. [PubMed: 15352785]

17. Hemmingsen L, Damblon C, Antony J, Jensen M, Adolph HW, Wommer S, Roberts GCK, Bauer R. J. Am. Chem. Soc. 2001; 123:10329-10335. [PubMed: 11603983]

18. Kofod P, Bauer R, Danielsen E, Larsen E, Bjerrum MJ. Eur. J. Biochem. 1991; 198:607-611. [PubMed: 2050141]

19. Bauer R, Bjerrum MJ, Danielsen E, Kofod P. Acta Chem. Scand. 1991; 45:593-603. [PubMed: 1764331]

20. Busenlehner LS, Cosper NJ, Scott RA, Rosen BP, Wong MD, Giedroc DP. Biochemistry. 2001; 40:4426-4436. [PubMed: 11284699]

21. Erskine PT, Norton E, Cooper JB, Lambert R, Coker A, Lewis G, Spencer P, Sarwar M, Wood SP, Warren MJ, Shoolingin-Jordan PM. Biochemistry. 1999; 38:4266-4276. [PubMed: 10194344]

22. Stempniak M, Hostomska Z, Nodes BR, Hostomsky Z. J. Virol. 1997; 71:2881-2886. [PubMed: 9060645]

23. Dieckmann GR, McRorie DK, Tierney DL, Utschig LM, Singer CP, O'Halloran TV, Penner-Hahn JE, DeGrado WF, Pecoraro VL. J. Am. Chem. Soc. 1997; 119:6195-6196.

24. a) Dieckmann GR, McRorie DK, Lear JD, Sharp KA, DeGrado WF, Pecoraro VL. J. Mol. Biol. 1998; 280:897-912. [PubMed: 9671558] b) Peacock AFA, Iranzo O, Pecoraro VL. Dalton Trans. 2009

25. Matzapetakis M, Farrer BT, Weng T-C, Hemmingsen L, Penner-Hahn JE, Pecoraro VL. J. Am. Chem. Soc. 2002; 124:8042-8054. [PubMed: 12095348]

26. Ghosh D, Lee K-H, Demeler B, Pecoraro VL. Biochemistry. 2005; 44:10732-10740. [PubMed: 16060682]

27. Matzapetakis M, Ghosh D, Weng K-H, Penner-Hahn JE, Pecoraro VL. J. Biol. Inorg. Chem. 2006; 11:876-890. [PubMed: 16855818]

28. Lee K-H, Matzapetakis M, Mitra S, Marsh ENG, Pecoraro VL. J. Am. Chem. Soc. 2004; 126:9178-9179. [PubMed: 15281796]

29. Iranzo O, Ghosh D, Pecoraro VL. Inorg. Chem. 2006; 45:9959-9973. [PubMed: 17140192]

30. Lee K-H, Cabello C, Hemmingsen L, Marsh ENG, Pecoraro VL. Angew. Chem. 2006; 118:29302934. Angew. Chem. Int. Ed.2006, 45, $2864-2868$.

31. Iranzo O, Cabello C, Pecoraro VL. Angew. Chem. 2007; 119:6808-6811. Angew. Chem. Int. Ed. 2007, 46, $6688-6691$.

32. Matthews RG, Goulding CW. Curr. Opin. Chem. Biol. 1997; 1:332-339. [PubMed: 9667865] 
33. Erskine PT, Senior N, Awan S, Lambert R, Lewis G, Tickle IJ, Sarwar M, Spencer P, Thomas P, Warren MJ, Shoolingin-Jordan PM, Wood SP, Cooper JB. Nat. Struct. Biol. 1997; 4:1025-1031. [PubMed: 9406553]

34. González B, Pajares MA, Martínez-Ripoll M, Blundell TL, Sanz-Aparicio J. J. Mol. Biol. 2004; 338:771-782. [PubMed: 15099744]

35. Kim JL, Morgenstern KA, Lin1 TFC, Dwyer MD, Landro JA, Chambers SP, Markland W, Lepre CA, O’Malley ET, Harbeson SL, Rice CM, Murcko MA, Caron PR, Thomson JA. Cell. 1996; 87:343-355. [PubMed: 8861917]

36. Rice WG, Supko JG, Malspeis L, Clanton RWBD Jr, Bu M, Graham L, Schaeffer CA, Turpin JA, Domagala J, Gogliotti R, Bader JP, Halliday SM, Coren L, S RC II, Arthur LO, Henderson LE. Science. 1995; 270:1194-1197. [PubMed: 7502043]

37. Cai M, Zheng R, Caffrey M, Craigie R, Clore GM, Gronenborn AM. Nat. Struct. Biol. 1997; 4:567-577. [PubMed: 9228950]

38. Santos RA, Gruff ES, Koch SA, Harbison GS. J. Am. Chem. Soc. 1991; 113:469-475.

39. Alberts IL, Nadassy K, Wodak SJ. Protein Sci. 1998; 7:1700-1716. [PubMed: 10082367]

40. Coyne HJ III, Ciofi-Baffoni S, Banci L, Bertini I, Zhang L, George GM, Winge DR. J. Biol. Chem. 2007; 282:8926-8934. [PubMed: 17215247]

41. Castro C, Millian NS, Garrow TA. Arch. Biochem. Biophys. 2008; 472:26-33. [PubMed: 18262489]

42. Parkin G. Chem. Rev. 2004; 104:699-767. [PubMed: 14871139]

43. Docommun, Y.; Merbach, AE., et al. Inorganic High Pressure Chemistry: Kinetics and Mechanisms. Eldik, Rv, editor. Amsterdam: Elsevier; 1986. p. 70

44. Peacock AFA, Hemmingsen L, Pecoraro VL. Proc. Natl. Acad. Sci. USA. 2008; 105:1656616571. [PubMed: 18940928]

45. Boggess RK, Absher JR, Morelen S, Taylor LT, Hughes JW. Inorg. Chem. 1983; 22:1273-1279.

46. Cheesman BV, Arnold AP, Rabenstein DL. J. Am. Chem. Soc. 1988; 110:6359-6364.

47. Farrer BT, Harris NP, Balchus KE, Pecoraro VL. Biochemistry. 2001; 40:14696-14705. [PubMed: 11724584]

48. Ghosh D, Pecoraro VL. Inorg. Chem. 2004; 43:7902-7915. [PubMed: 15578824]

49. Iranzo O, Thulstrup PV, Ryu S-B, Hemmingsen L, Pecoraro VL. Chem. Eur. J. 2007; 13:91789190. [PubMed: 17960740]

50. Touw DS, Nordman CE, Stuckey JA, Pecoraro VL. Proc. Natl. Acad. Sci. USA. 2007; 104:11969_ 11974. [PubMed: 17609383]

51. Farrer BT, McClure CP, Penner-Hahn JE, Pecoraro VL. Inorg. Chem. 2000; 39:5422-5423. [PubMed: 11154553]

52. Shaikh TA, Bakus RC II, Parkin S, Atwood DA. J. Organomet. Chem. 2006; 691:1825-1833.

53. Shaikh TA, Parkin S, Atwood DA. J. Organomet. Chem. 2006; 691:4167.

54. Shi W, Dong J, Scott RA, Ksenzenko MY, Rosen BP. J. Biol. Chem. 1996; 271:9291-9297. [PubMed: 8621591]

55. Carter TG, Healey ER, Pitt MA, Johnson DW. Inorg. Chem. 2005; 44:9634-9636. [PubMed: 16363829]

56. Erskine PT, Duke EMH, Tickle IJ, Senior NM, Warren MJ, Cooper JB. Acta Crystallogr. Sect. D. 2000; 56:421-430. [PubMed: 10739915]

57. Dean PAW, Vittal JJ, Payne NC. Inorg. Chem. 1984; 23:4232-4236.

58. Christou G, Folting K, Huffman JC. Polyhedron. 1984; 3:1247-1253.

59. Magyar JS, Weng T-C, Stern CM, Dye DF, Rous BW, Payne JC, Bridgewater BM, Mijovilovich A, Parkin G, Zaleski JM, Penner-Hahn JE, Godwin HA. J. Am. Chem. Soc. 2005; 127:9495-9505. [PubMed: 15984876]

60. Busenlehner LS, Weng T-C, Penner-Hahn JE, Giedroc DP. J. Mol. Biol. 2002; 319:685-701. [PubMed: 12054863]

61. Cai M, Huang Y, Caffrey M, Zheng R, Craigie R, Clore GM, Gronenborn AM. Protein Sci. 1998; 7:2669-2674. [PubMed: 9865962] 
62. Govindaswamy N, Moy J, Millar M, Koch SA. Inorg. Chem. 1992; 31:5343-5344.

63. Chan, WC.; White, PD. Fmoc Solid Phase Peptide Synthesis: A Practical Approach. New York: Oxford University Press; 2000.

64. Hemmingsen L, Bauer R, Bjerrum MJ, Zeppezauer M, Adolph HW, Formicka G, CedergrenZeppezauer E. Biochemistry. 1995; 34:7145-7153. [PubMed: 7766625]

65. Hemmingsen LB, Bjerrum R, Adolph M, Zeppezauer H, Cedergren-Zeppezauer ME. Eur. J. Biochem. 1996; 241:546-551. [PubMed: 8917454]

66. Ellman GL. Arch. Biochem. Biophys. 1959; 82:70-77. [PubMed: 13650640]

67. Mantle M, Stewart G, Zayas G, King M. Biochem. J. 1990; 266:597-604. [PubMed: 2317206]

68. Cobas, C.; Cruces, J.; Sardina, FJ. MestRe-C Version 2.3. Spain: Universidad de Santiago de Compostela; 2000. 

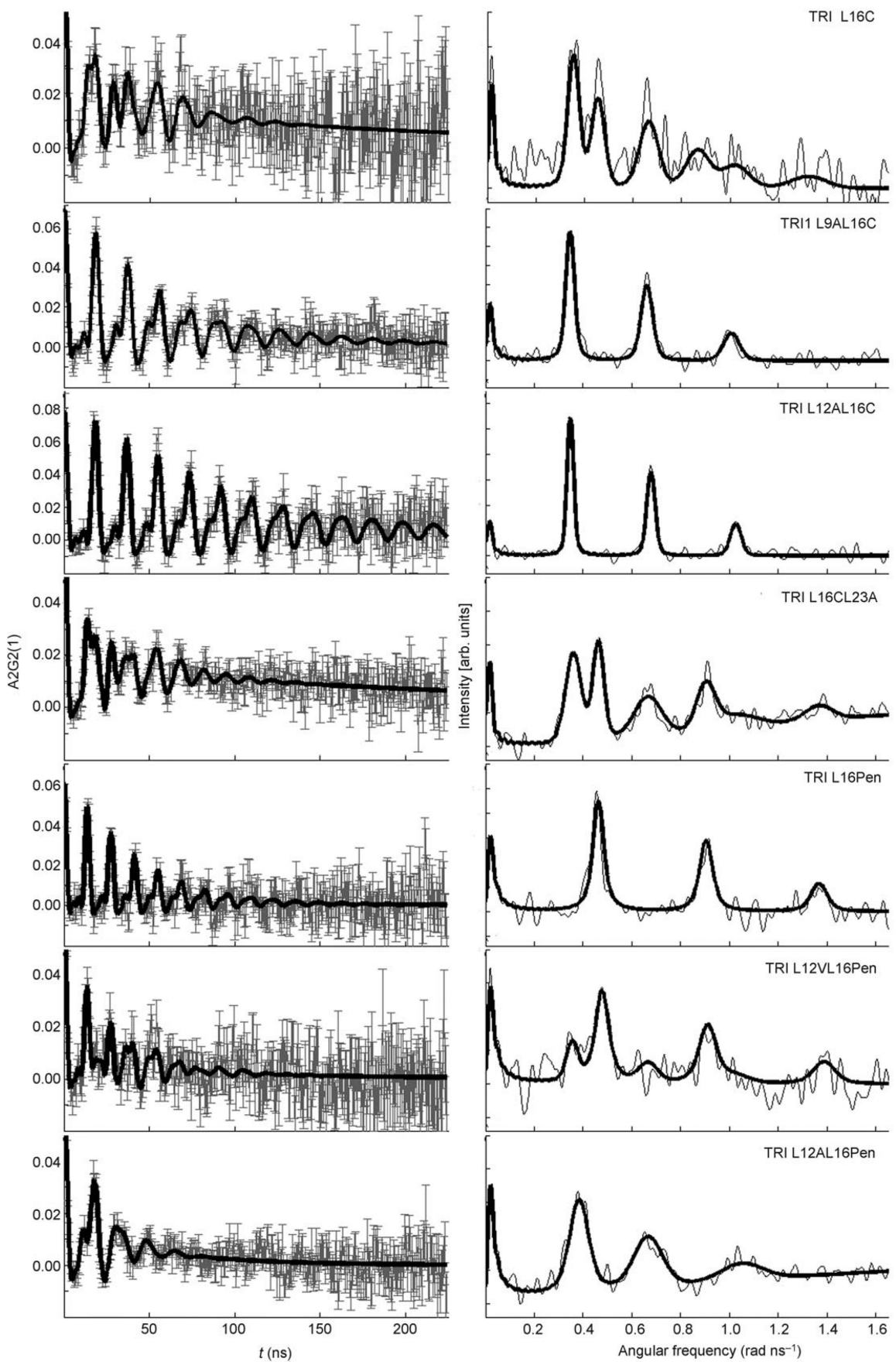

Figure 1.

${ }^{111 \mathrm{~m}} \mathrm{Cd}$ PAC spectra of the different TRI peptides. All the samples contained $20 \mathrm{~m}_{\mathrm{M}}$ TRIS buffer, $300 \mu_{\mathrm{m}}$ peptide and a Cd ${ }^{\mathrm{II}} /$ peptide ratio of 1:12. Left: Perturbation function (experimental data with error bars are shown in grey, fit shown as solid line); right: the Fourier transform (the thin line gives the Fourier transform of the experimental data, and the bold faced line gives the Fourier transform of the fit). 


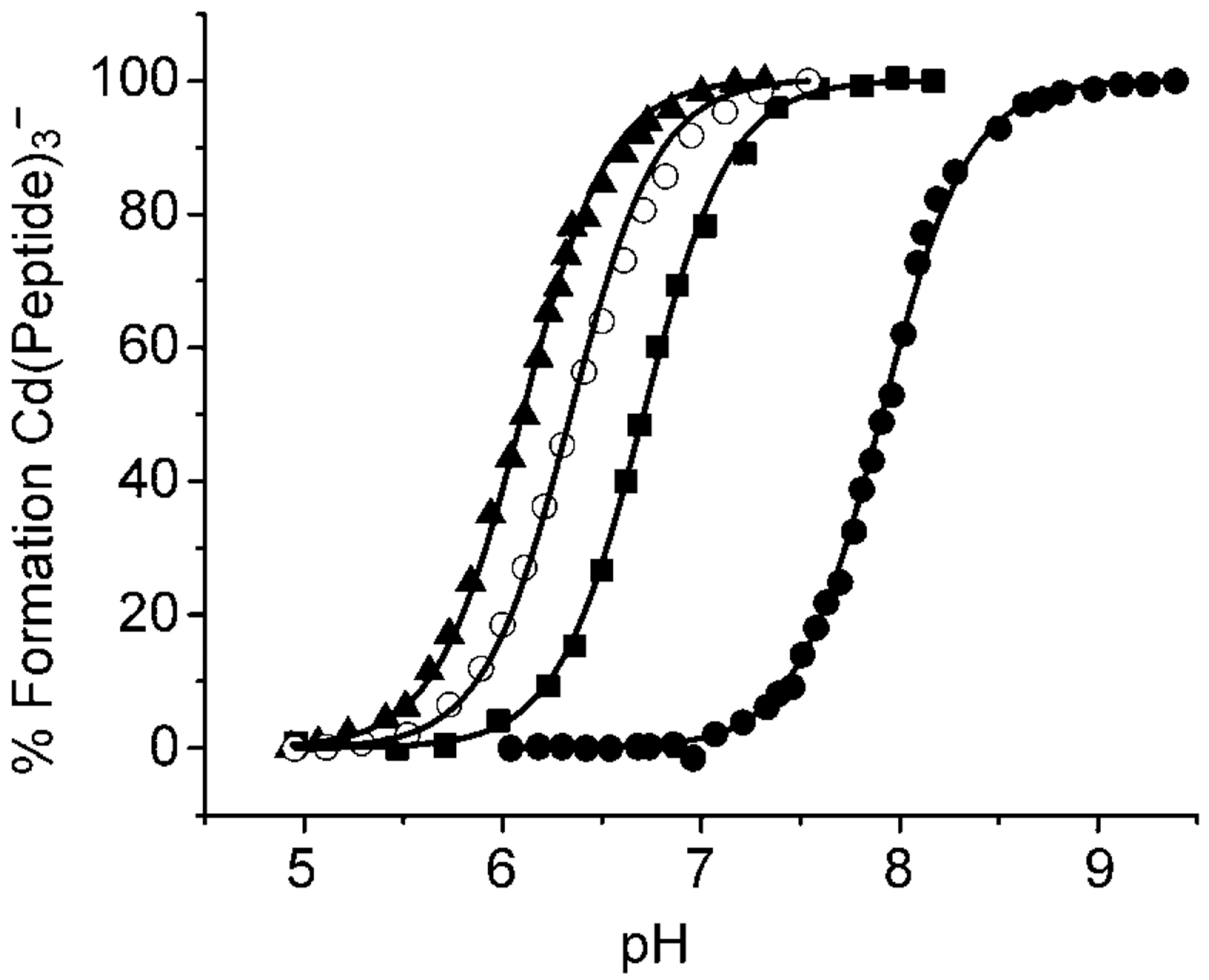

Figure 2.

$\mathrm{pH}$ dependence of $\mathrm{Cd}^{\mathrm{II}}$ binding to TRI peptides that contain fully 4-coordinate and fully 3-

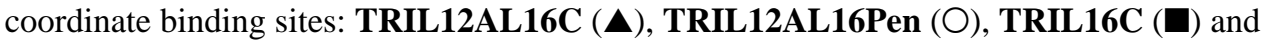
TRIL16Pen (O). The solid lines represent the fit to the simultaneous deprotonation model. 


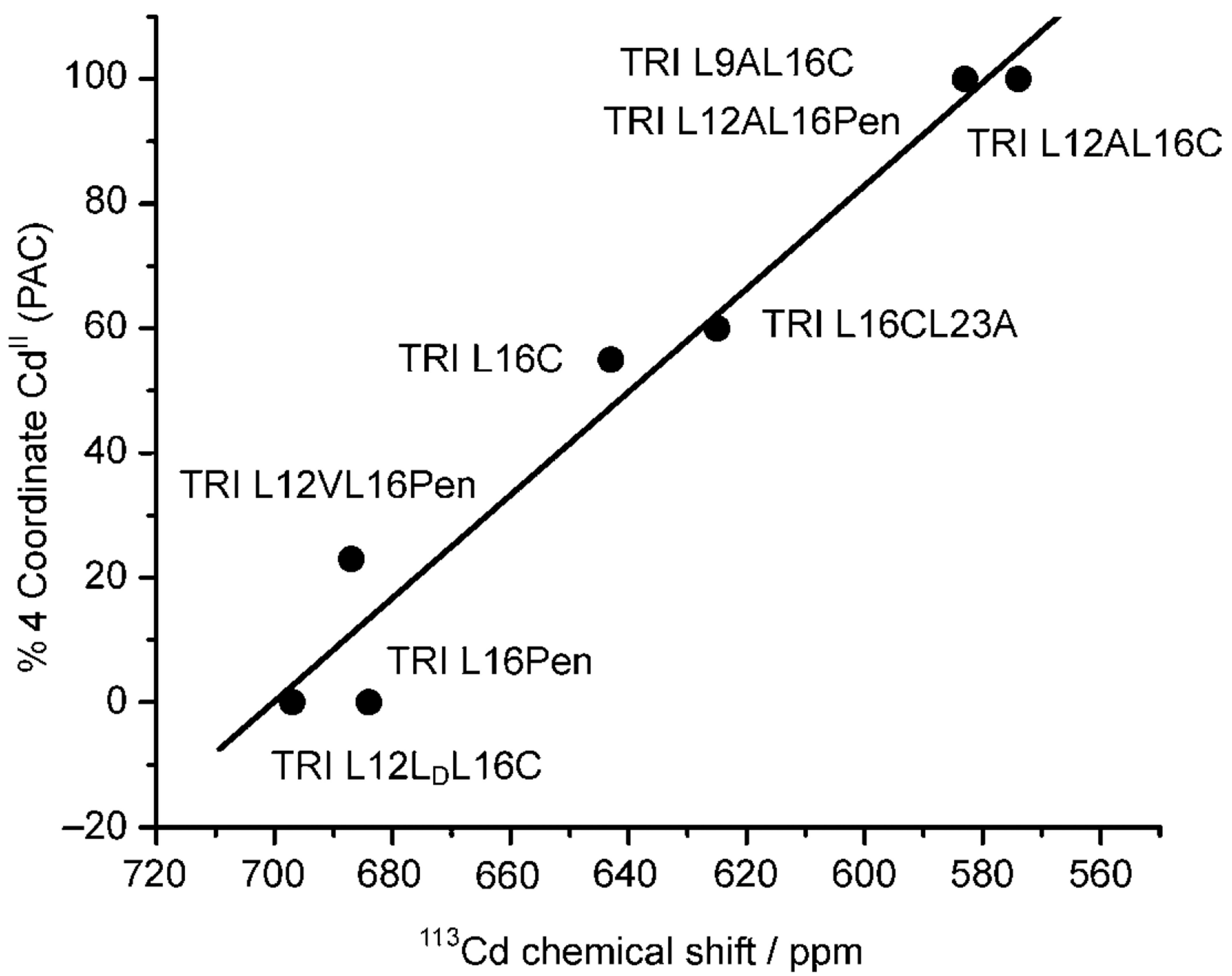

Figure 3.

Plot of the percentage of 4-coordinate $\mathrm{Cd}^{\mathrm{II}}$ calculated based on the ${ }^{111 \mathrm{~m}} \mathrm{Cd}$ PAC spectroscopic data vs the ${ }^{113} \mathrm{Cd}$ chemical shift for different TRI peptides. The solid line represents the linear fit of the experimental data $\left(r^{2}=0.97414\right)$. 


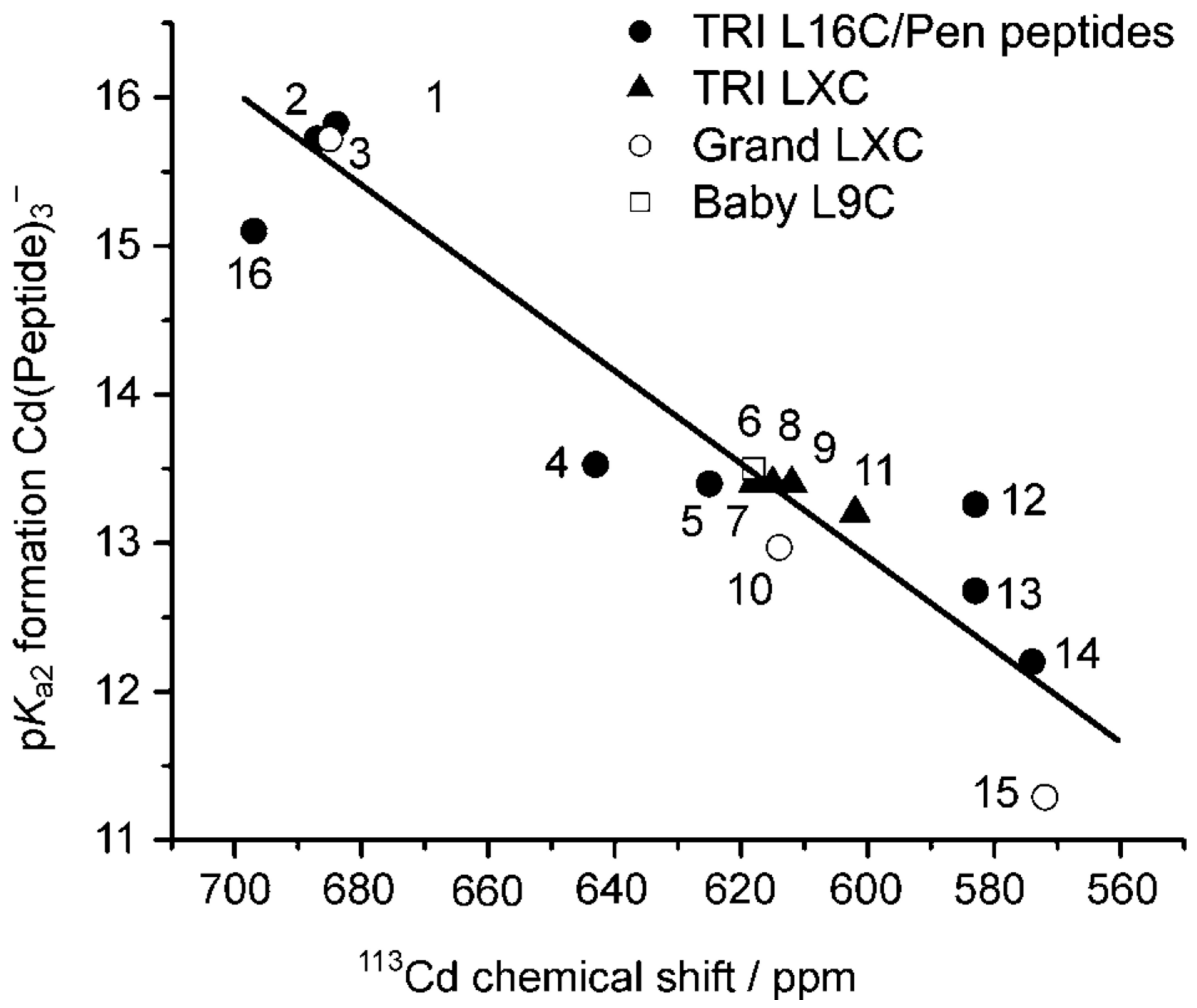

Figure 4.

Plot of the $\mathrm{p} K_{\mathrm{a} 2}$ value for the formation of the complex Cd-(peptide) ${ }_{3}{ }^{-}$vs the ${ }^{113} \mathrm{Cd}$ chemical shift for different peptides of the TRI family and derivatives: 1) TRIL16Pen; 2) TRIL12VL16Pen; 3) GRANDL16Pen; 4) TRIL16CL23A; 5) TRIL16C; 6) BABYL9C; 7) TRIL2WL9C; 8) TRIL9C; 9) TRIL23C; 10) GRANDL9C; 11) CSL9C; 12) TRIL9AL16C; 13) TRIL12AL16Pen; 14) TRIL12AL16C; 15) GRANDL12AL16C; 16)

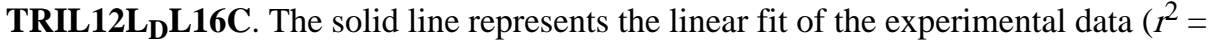
0.9468) 


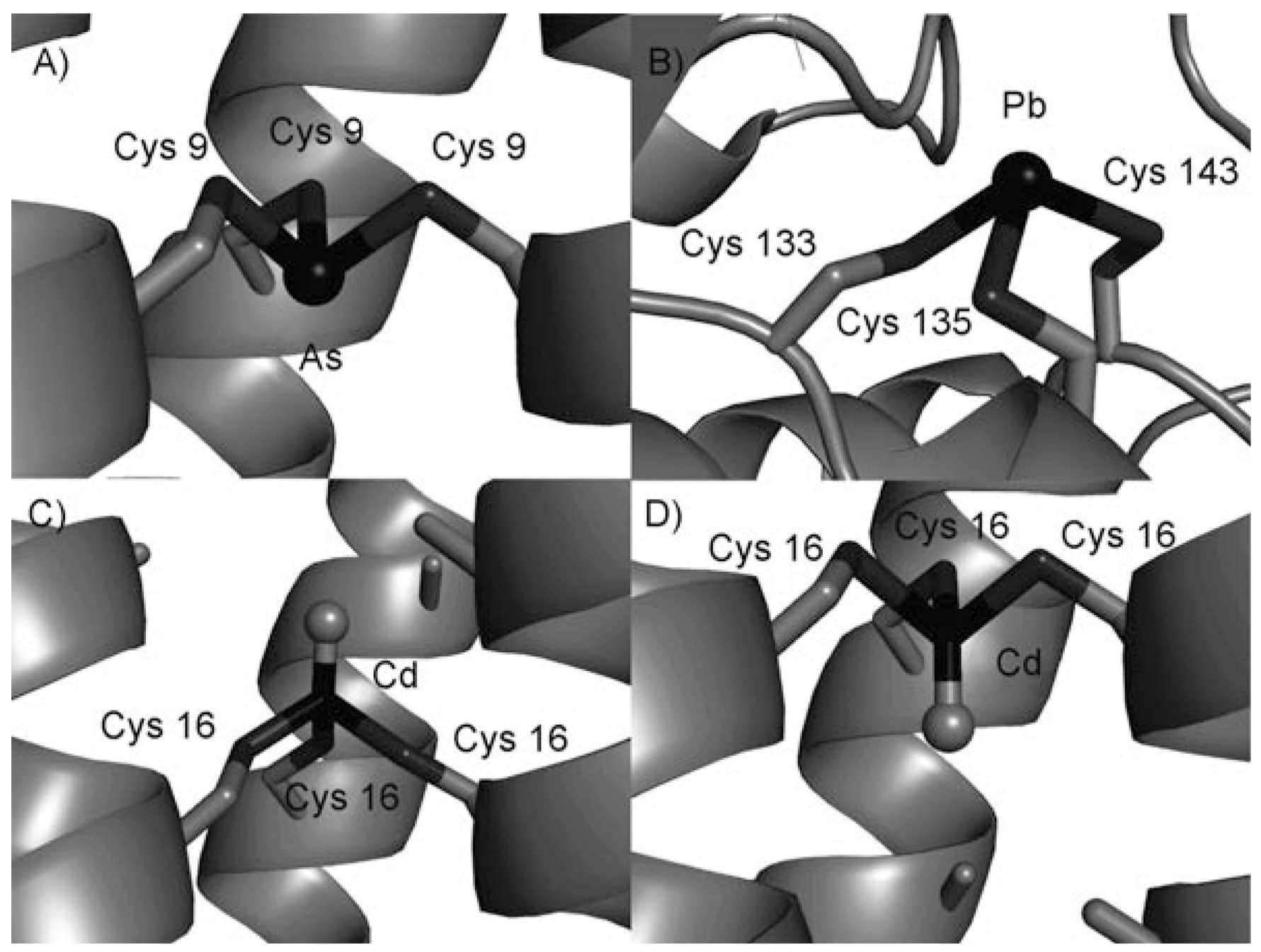

Figure 5.

a) Side-view of As ${ }^{\mathrm{III}}$ coordinated to the Cys residues in CSL9C. ${ }^{[50]}$ b) Drawing generated using the X-ray crystal structure of $\mathrm{Pb}^{\mathrm{II}}$ bound to ALAD (pdb: 1QNV) ${ }^{[56]}$ Models, based on the X-ray crystal structure of $\mathrm{As}(\mathrm{CSL9C})_{3}{ }^{[50]}$ of $\mathrm{CdS}_{3} \mathrm{O}$ bound c) to TRIL12AL16C in the exo conformation and d) to TRIL16CL19A in the endo conformation. All figures were generated using PyMOL. 


\section{Table 1}

Peptide sequence examples of the TRI peptide family and derivatives.

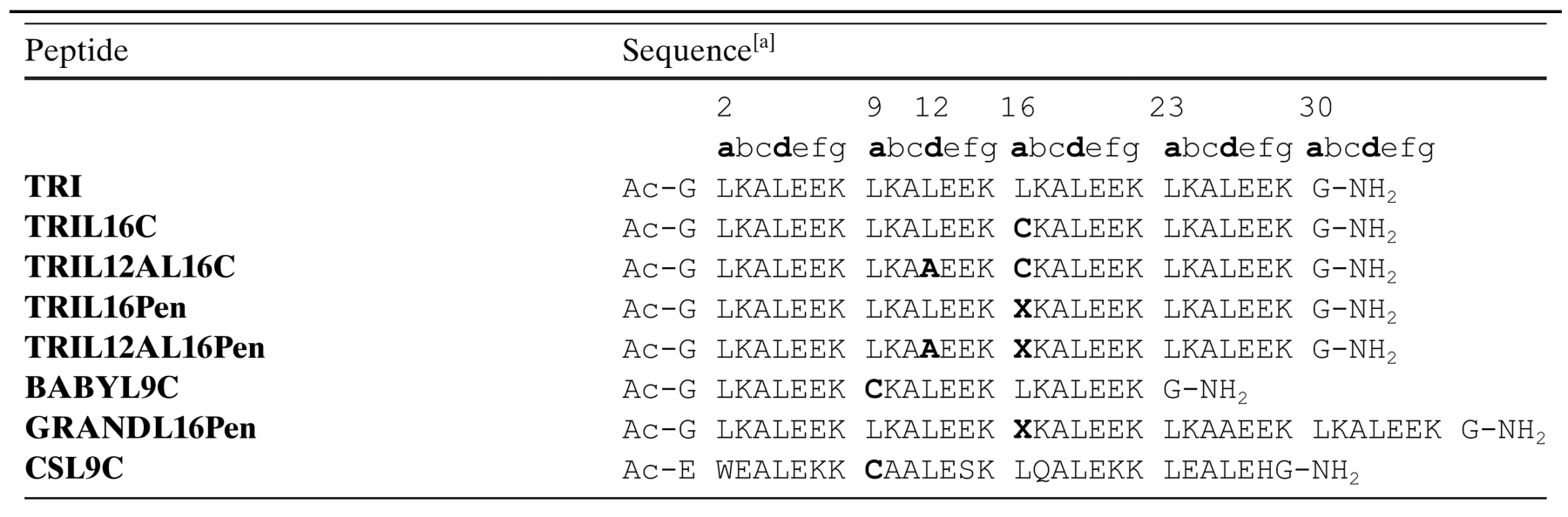

${ }^{[a]} \mathbf{X}=$ Penicillamine. Residues in bold indicate modifications. 


\section{Table 3}

Percentage of $\mathrm{Cd}^{\mathrm{II}}$ species based on ${ }^{111 \mathrm{~m}} \mathrm{Cd}$ PAC spectroscopic data, $\mathrm{p} K_{\mathrm{a} 2}$ values for $\mathrm{Cd}^{\mathrm{II}}$ binding and ${ }^{113} \mathrm{Cd}$ NMR chemical shifts for the different TRI peptides and derivates.

\begin{tabular}{|c|c|c|c|c|}
\hline Peptide & $\begin{array}{l}\% \text { Cd }^{\mathrm{II}} \text { Species } \\
\text { 4-coordinate } \mathrm{S}_{3}(\mathrm{O} / \mathrm{N})\end{array}$ & 3-coordinate $S_{3}$ & Apparent $\mathrm{p} K_{\mathrm{a} 2}$ & ${ }^{113}$ Cd NMR (ppm) \\
\hline TRIL16C & 60 & 40 & $13.4 \pm 0.2^{[a]}$ & $625^{[b]}$ \\
\hline TRIL9AL16C & 100 & 0 & $13.3 \pm 0.2$ & $583^{[c]}$ \\
\hline TRIL12AL16C & 100 & 0 & $12.2 \pm 0.2^{[d]}$ & $574[c]$ \\
\hline TRIL16CL23A & 55 & 45 & $13.5 \pm 0.2$ & 643 \\
\hline TRIL16Pen & 0 & 100 & $15.8 \pm 0.2^{[e]}$ & $684^{[f]}$ \\
\hline TRIL12VL16Pen & 22 & 78 & $15.7 \pm 0.2$ & 687 \\
\hline TRIL12AL16Pen & 100 & 0 & $12.7 \pm 0.2$ & 583 \\
\hline TRIL9C & - & - & $13.4 \pm 0.2\lceil g]$ & $615^{[g]}$ \\
\hline TRIL2WL9C & - & - & $13.4 \pm 0.2^{\lceil g]}$ & $618^{[g]}$ \\
\hline TRIL23C & - & - & $13.4 \pm 0.2^{[g]}$ & $612^{[g]}$ \\
\hline GRANDL9C & - & - & $13.0 \pm 0.2$ & 614 \\
\hline GRANDL12AL16C & - & - & $11.3 \pm 0.2$ & 572 \\
\hline GRANDL16Pen & - & - & $15.7 \pm 0.2^{[d]}$ & 685 \\
\hline BABYL9C & - & - & $13.5 \pm 0.2$ & 618 \\
\hline CSL9C & - & - & $13.2 \pm 0.2[g]$ & $602^{[g]}$ \\
\hline \multicolumn{5}{|l|}{${ }^{[a]}$ From ref. [27]. } \\
\hline \multicolumn{5}{|l|}{ [b] From ref. [25]. } \\
\hline \multicolumn{5}{|l|}{${ }^{[c]}$ From ref. [28]. } \\
\hline \multicolumn{5}{|l|}{${ }^{[d]}$ From ref. [31]. } \\
\hline \multicolumn{5}{|c|}{${ }^{[e]}$ An incorrect value (typo) of 15.3 was reported in ref. [31]. } \\
\hline \multicolumn{5}{|l|}{${ }^{[f]}$ From ref. [30]. } \\
\hline From ref. [29]. & & & & \\
\hline
\end{tabular}

